\title{
Repetitively pulsed atmospheric pressure discharge treatment of rough polymer surfaces: II. Treatment of micro-beads in $\mathrm{He} / \mathrm{NH}_{3} / \mathrm{H}_{2} \mathrm{O}$ and $\mathrm{He} / \mathrm{O}_{2} / \mathrm{H}_{2} \mathrm{O}$ mixtures
}

\author{
Ananth N Bhoj ${ }^{1,3}$ and Mark J Kushner ${ }^{2,4}$ \\ ${ }^{1}$ Department of Chemical and Biomolecular Engineering, University of Illinois, Urbana, IL 61801, USA \\ ${ }^{2}$ Department of Electrical and Computer Engineering, Iowa State University, Ames, IA 50011, USA \\ E-mail: ananth.bhoj@novellus.com and mjk@iastate.edu
}

Received 8 March 2008, in final form 29 May 2008

Published 31 July 2008

Online at stacks.iop.org/PSST/17/035025

\begin{abstract}
Plasmas are increasingly being used to functionalize the surface of polymers having complex shapes for biomedical applications such as tissue scaffolds and drug delivering micro-beads. The functionalization often requires affixation of amine $\left(\mathrm{NH}_{2}\right)$ or O-containing groups. In this paper, results are discussed from a two-dimensional computational investigation of the atmospheric pressure plasma functionalization of non-planar and porous surfaces of polypropylene with $\mathrm{NH}_{x}$ and $\mathrm{O}$-containing groups. For the former, the discharge is sustained in $\mathrm{He} / \mathrm{NH}_{3} / \mathrm{H}_{2} \mathrm{O}$ mixtures in a dielectric barrier-corona configuration. Significant microscopic non-uniformities arise due to competing pathways for reactive gas phase radicals such as $\mathrm{OH}$ and $\mathrm{NH}_{2}$, and on the surface by the availability of $\mathrm{OH}$ to initiate amine attachment. The treatment of inside surfaces of porous polymer micro-beads placed on an electrode is particularly sensitive to view angles to the discharge and pore size, and is ultimately controlled by the relative rates of radical transport and surface reactions deep into the pores. The functionalization of micro-beads suspended in $\mathrm{He} / \mathrm{O}_{2} / \mathrm{H}_{2} \mathrm{O}$ discharges is rapid with comparable treatment of the outer and interior surfaces, but varies with the location of the micro-bead in the discharge volume.
\end{abstract}

(Some figures in this article are in colour only in the electronic version)

\section{Introduction}

Polymer surfaces are often modified with functional groups for biomedical applications such as immobilization of biomolecules or enzymes [1], preparation of anti-coagulant surfaces, cell patterning and tissue engineering [2]. In general, $\mathrm{N}$-containing groups such as $\mathrm{R}-\mathrm{NH}_{2}$ (R represents the polymer backbone) and $\mathrm{O}$-containing groups such as $(\mathrm{O}=\mathrm{C}-\mathrm{OH})$ are favored in biomedical applications for their ability to interact with a wide variety of biomolecules. Often, the primary amino $\left(-\mathrm{NH}_{2}\right)$ groups serve as binding sites for spacer molecules

3 Present address: Novellus Systems, Inc., 3011 N. 1st St, San Jose, CA 95134, USA.

${ }^{4}$ Author to whom any correspondence should be addressed. to interlock during immobilization [3]. Traditionally, low pressure plasmas sustained in $\mathrm{N}_{2}$ or $\mathrm{N}$-containing gases such as $\mathrm{NH}_{3}$ are used for such functionalization. Hayat et al [4] used ammonia radio frequency (rf) discharges at $75 \mathrm{mTorr}$ and $10 \mathrm{~W}$ to modify polyethylene (PE) surfaces with $-\mathrm{NH}_{2}$ groups to subsequently immobilize proteins. They found that surface modification occurs rapidly within 1 min of treatment, increasing $-\mathrm{NH}_{2}$ coverage from $0 \%$ up to $7 \%$. For the same power input, longer treatment times were required to achieve a similar $-\mathrm{NH}_{2}$ coverage at 300 mTorr.

Holmes and Schwartz [5] used $\mathrm{NH}_{3}$-plasmas at 1 Torr to functionalize PE surfaces varying the power from 5 to $100 \mathrm{~W}$ and the time of treatment from 1 to $10 \mathrm{~min}$. They found that optimal $-\mathrm{NH}_{2}$ coverages were obtained by using 
intermediate power and treatment times. In the work of Liu et al, the surfaces of micro-porous polypropylene (PP) membranes were functionalized with $-\mathrm{NH}_{2}$ groups using ammonia plasmas generated at higher pressures of tens of Torr to enable subsequent covalent bonding of polypeptides to the surface [6]. Such polymer surfaces can be rough to serve as scaffolds to promote cell growth in tissue engineering or to enhance the biocompatibility of implants [7].

Plasmas are also used to functionalize the surfaces of polymer micro-beads and powders in order to improve surface reactivity and biocompatibility [8-10]. Sipehia et al used an ammonia plasma to place amino $\left(-\mathrm{NH}_{2}\right)$ groups on the surfaces of PP beads to serve as bonding sites for enzyme molecules [11]. The surface reactivity of the polymer can markedly change even when new chemical groups cover only a small fraction of the surface. The inert pore surfaces of macro-porous PE used in chromatographic columns were treated downstream of the ammonia discharge to make them reactive enough to bind colloidal particles [12].

Uniformly treating the surfaces of powders and internal surfaces of porous materials is challenging. Fluidized bed reactors have improved the uniformity of functionalization and deposition on small particles by suspending them in the reactive medium during treatment [13]. Pharmaceutical powders are treated in atmospheric pressure corona discharges leveraging surface charging of the particles to reduce agglomeration [14].

In part I [15], the use of humid air atmospheric pressure discharges to treat rough polymer surfaces was discussed. In this paper, we discuss results from a computational investigation on using atmospheric pressure discharges for functionalization of rough surfaces as might be encountered in tissue scaffolding and porous micro-beads for drug delivery. Similarly to part I, a repetitively pulsed $10 \mathrm{kHz}$ corona discharge with a gap of $2 \mathrm{~mm}$ operating in a dielectric-barrier configuration with $\mathrm{He} / \mathrm{NH}_{3} / \mathrm{H}_{2} \mathrm{O}$ and $\mathrm{He} / \mathrm{O}_{2} / \mathrm{H}_{2} \mathrm{O}$ gas mixtures is considered. The discharge pulses are short $(<10 \mathrm{~ns})$ followed by an interpulse period (IP) of $100 \mu \mathrm{s}-1 \mathrm{~ms}$. The two-dimensional plasma hydrodynamics and surface kinetics model, and reaction mechanisms used in this study are described in section 2. In section 3, results from simulations of discharges in $\mathrm{He} / \mathrm{NH}_{3} / \mathrm{H}_{2} \mathrm{O}$ mixtures to affix amine $\left(-\mathrm{NH}_{2}\right)$ groups on rough PP surfaces are discussed. In section 4 , the functionalization of the surfaces of porous micro-beads tens of micrometers in size with pore diameters a few micrometers in $\mathrm{He} / \mathrm{NH}_{3} / \mathrm{H}_{2} \mathrm{O}$ discharges is discussed to determine the accessibility of reactive species generated in the discharge to internal surfaces. The treatment of porous micro-beads suspended in the discharge volume of discharges sustained in $\mathrm{He} / \mathrm{O}_{2} / \mathrm{H}_{2} \mathrm{O}$ is discussed in section 5. Concluding remarks are in section 6 .

\section{Description of the model and reaction mechanisms}

The two-dimensional modeling platform, non-PDPSIM, used in this investigation is the same as described in part I [15]. The gas phase reaction mechanism used for the $\mathrm{He} / \mathrm{NH}_{3} / \mathrm{H}_{2} \mathrm{O}$ discharges is discussed in detail in [16] and includes 40 species (15 charged). The mechanism is briefly discussed.

Electron impact reactions of $\mathrm{NH}_{3}$ resulting in vibrational excitation, dissociative excitation and ionization are included:

$$
\begin{gathered}
\mathrm{e}+\mathrm{NH}_{3} \rightarrow \mathrm{NH}_{3}(v)+\mathrm{e}, \\
\mathrm{e}+\mathrm{NH}_{3} \rightarrow \mathrm{NH}_{2}+\mathrm{H}+\mathrm{e}, \\
\mathrm{e}+\mathrm{NH}_{3} \rightarrow \mathrm{NH}+\mathrm{H}+\mathrm{H}+\mathrm{e}, \\
\mathrm{e}+\mathrm{NH}_{3} \rightarrow \mathrm{NH}_{3}^{+}+\mathrm{e} .
\end{gathered}
$$

Dissociation products are $\mathrm{NH}_{2}, \mathrm{NH}$ and $\mathrm{H}$. Electron impact dissociation of $\mathrm{H}_{2} \mathrm{O}$ produces $\mathrm{OH}$ and $\mathrm{H}$, as discussed in part $\mathrm{I}$. Although the densities of excited states of $\mathrm{He}(19.8 \mathrm{eV})$ and $\mathrm{He}^{+}(24.5 \mathrm{eV})$ are low, their energies are high enough to chargeexchange or Penning ionize, and so dissociate $\mathrm{NH}_{3}$,

$\mathrm{He}^{*}+\mathrm{NH}_{3} \rightarrow \mathrm{NH}_{3}^{+}+\mathrm{He}+\mathrm{e} \quad\left(k=4.2 \times 10^{-11} \mathrm{~cm}^{3} \mathrm{~s}^{-1}\right)$,
$\mathrm{He}^{*}+\mathrm{NH}_{3} \rightarrow \mathrm{NH}_{2}+\mathrm{H}+\mathrm{He} \quad\left(k=5.8 \times 10^{-11} \mathrm{~cm}^{3} \mathrm{~s}^{-1}\right)$,
$\mathrm{He}^{*}+\mathrm{NH}_{3} \rightarrow \mathrm{NH}+\mathrm{H}+\mathrm{H}+\mathrm{He} \quad\left(k=5.2 \times 10^{-11} \mathrm{~cm}^{3} \mathrm{~s}^{-1}\right)$,

$\mathrm{He}^{+}+\mathrm{NH}_{3} \rightarrow \mathrm{NH}_{3}^{+}+\mathrm{He} \quad\left(k=1.3 \times 10^{-9} \mathrm{~cm}^{3} \mathrm{~s}^{-1}\right)$,

$\mathrm{He}^{+}+\mathrm{NH}_{3} \rightarrow \mathrm{NH}_{2}^{+}+\mathrm{H}+\mathrm{He} \quad\left(k=5.5 \times 10^{-11} \mathrm{~cm}^{3} \mathrm{~s}^{-1}\right)$,

where $k$ is the rate coefficient at room temperature. Chargeexchange reactions of $\mathrm{He}^{+}$with $\mathrm{NH}$ and $\mathrm{NH}_{2}$ produces their respective $\mathrm{NH}_{x}^{+}$ions. Further charge-exchange reactions between these $\mathrm{NH}_{x}^{+}$ions and other species leads to formation of $\mathrm{NH}_{4}^{+}$which has the smallest ionization potential among the ions in the mechanism,

$\mathrm{NH}_{3}^{+}+\mathrm{NH}_{3} \rightarrow \mathrm{NH}_{4}^{+}+\mathrm{NH}_{2} \quad\left(k=2.2 \times 10^{-9} \mathrm{~cm}^{3} \mathrm{~s}^{-1}\right)$.

As such, the density of $\mathrm{NH}_{4}^{+}$becomes large if $\mathrm{NH}_{x}$ species are not significantly depleted. Dissociative recombination of $\mathrm{NH}_{x}^{+}$ produces $\mathrm{NH}_{x-1}$ and $\mathrm{H}$ as the dominant channels.

$$
\begin{aligned}
& \mathrm{e}+\mathrm{NH}_{4}^{+} \rightarrow \mathrm{NH}_{3}+\mathrm{H} \\
& \quad\left(k=9.0 \times 10^{-7} T_{\mathrm{e}}^{-0.6} \mathrm{~cm}^{3} \mathrm{~s}^{-1}, \Delta \mathrm{H}=-4.7 \mathrm{eV}\right), \\
& \mathrm{e}+\mathrm{NH}_{4}^{+} \rightarrow \mathrm{NH}_{2}+\mathrm{H}+\mathrm{H} \\
& \quad\left(k=1.5 \times 10^{-7} T_{\mathrm{e}}^{-0.6} \mathrm{~cm}^{3} \mathrm{~s}^{-1}, \Delta \mathrm{H}=-0.3 \mathrm{eV}\right),
\end{aligned}
$$

where the electron temperature $T_{\mathrm{e}}$ is in $\mathrm{eV}$.

Between discharge pulses, neutral radical chemistry dominates the mechanism. At this time the bulk of the dissociated $\mathrm{NH}_{3}$ is in the form of $\mathrm{H}$ and $\mathrm{NH}_{2}$. At atmospheric pressure, rapid three-body reactions promote recombination of radicals into more stable products in a few milliseconds,

$$
\begin{aligned}
& \mathrm{H}+\mathrm{H}+\mathrm{He} \rightarrow \mathrm{H}_{2}+\mathrm{He} \quad\left(k=2.1 \times 10^{-30} T_{\mathrm{g}}^{-1} \mathrm{~cm}^{6} \mathrm{~s}^{-1}\right), \\
& \mathrm{H}+\mathrm{H}+\mathrm{NH}_{3} \rightarrow \mathrm{H}_{2}+\mathrm{NH}_{3} \quad\left(k=1.4 \times 10^{-31} \mathrm{~cm}^{6} \mathrm{~s}^{-1}\right),
\end{aligned}
$$

$\mathrm{H}+\mathrm{NH}_{2}+\mathrm{NH}_{3} \rightarrow \mathrm{NH}_{3}+\mathrm{NH}_{3} \quad\left(k=6.0 \times 10^{-30} \mathrm{~cm}^{6} \mathrm{~s}^{-1}\right)$.

The consumption of $\mathrm{H}$ radicals by three-body reactions with $\mathrm{NH}_{2}$ to form $\mathrm{NH}_{3}$ can be important as the rate coefficient for this reaction is large, particularly with $\mathrm{NH}_{3}$ as the third body. 
Formation of $\mathrm{N}_{2} \mathrm{H}_{x}(x=2,3,4)$ by two and threebody reactions also depletes $\mathrm{NH}_{2}$. The primary pathways for producing $\mathrm{N}_{2} \mathrm{H}_{x}$ are

$$
\begin{aligned}
& \mathrm{NH}_{2}+\mathrm{NH} \rightarrow \mathrm{N}_{2} \mathrm{H}_{2}+\mathrm{H} \quad\left(k=2.5 \times 10^{-9} T_{\mathrm{g}}^{-0.5} \mathrm{~cm}^{3} \mathrm{~s}^{-1}\right), \\
& \mathrm{NH}_{2}+\mathrm{NH} \rightarrow \mathrm{N}_{2} \mathrm{H}_{3} \quad\left(k=1.16 \times 10^{-10} \mathrm{~cm}^{3} \mathrm{~s}^{-1}\right), \\
& \quad\left(k=6.9 \times 10^{-30} \mathrm{~cm}^{6} \mathrm{~s}^{-1}\right) .
\end{aligned}
$$

$\mathrm{N}_{2} \mathrm{H}_{2}$ is depleted by reactions with $\mathrm{H}$ to form $\mathrm{NNH}$, a relatively short-lived species as its rate of decomposition to $\mathrm{N}_{2}$ and $\mathrm{H}$ is much faster than its production from $\mathrm{N}_{2} \mathrm{H}_{2}$,

$$
\begin{aligned}
& \mathrm{N}_{2} \mathrm{H}_{2}+\mathrm{H} \rightarrow \mathrm{NNH}+\mathrm{H}_{2} \\
& \quad\left(k=1.4 \times 10^{-17} T_{\mathrm{g}}^{2.63} \mathrm{e}^{115 / T_{\mathrm{g}}} \mathrm{cm}^{3} \mathrm{~s}^{-1}\right), \\
& \mathrm{NNH} \rightarrow \mathrm{N}_{2}+\mathrm{H} \quad\left(k=2.7 \times 10^{16} T_{\mathrm{g}}^{-0.53} \mathrm{e}^{-3404 / T_{\mathrm{g}}} \mathrm{s}^{-1}\right) .
\end{aligned}
$$

$\mathrm{NH}_{x}$ species also react with $\mathrm{OH}$ generated by electron impact dissociation of $\mathrm{H}_{2} \mathrm{O}$, for example, creating $\mathrm{NO}$ and $\mathrm{HNO}$,

$\mathrm{OH}+\mathrm{N} \rightarrow \mathrm{NO}+\mathrm{H} \quad\left(k=4.2 \times 10^{-11} \mathrm{~cm}^{3} \mathrm{~s}^{-1}\right)$,

$\mathrm{OH}+\mathrm{NH} \rightarrow \mathrm{H}+\mathrm{HNO} \quad\left(k=3 \times 10^{-12} \mathrm{~cm}^{3} \mathrm{~s}^{-1}\right)$,

$\mathrm{OH}+\mathrm{NH}_{x} \rightarrow \mathrm{H}_{2} \mathrm{O}+\mathrm{NH}_{x-1} \quad\left(k=3.32 \times 10^{-11} \mathrm{~cm}^{3} \mathrm{~s}^{-1}\right)$.

The products of these reactions can further react with other species, such as,

$$
\begin{aligned}
& \mathrm{HNO}+\mathrm{OH} \rightarrow \mathrm{H}_{2} \mathrm{O}+\mathrm{NO} \quad\left(k=2.4 \times 10^{-12} \mathrm{~cm}^{3} \mathrm{~s}^{-1}\right), \\
& \mathrm{HNO}+\mathrm{NH}_{2} \rightarrow \mathrm{NH}_{3}+\mathrm{NO} \quad\left(k=5.36 \times 10^{-12} \mathrm{~cm}^{3} \mathrm{~s}^{-1}\right), \\
& \mathrm{HNO}+\mathrm{H} \rightarrow \mathrm{H}_{2}+\mathrm{NO} \quad\left(k=3 \times 10^{-11} \mathrm{~cm}^{3} \mathrm{~s}^{-1}\right), \\
& \mathrm{NO}+\mathrm{N} \rightarrow \mathrm{O}+\mathrm{N}_{2} \quad\left(k=3 \times 10^{-11} \mathrm{~cm}^{3} \mathrm{~s}^{-1}\right), \\
& \mathrm{NO}+\mathrm{NH}_{2} \rightarrow \mathrm{N}_{2}+\mathrm{H}+\mathrm{OH} \quad\left(k=1.7 \times 10^{-11} \mathrm{~cm}^{3} \mathrm{~s}^{-1}\right)
\end{aligned}
$$

As discussed in part I, OH radicals produced in oxygen containing atmospheric pressure discharges rapidly react with the hydrocarbon polymer backbone by $\mathrm{H}$ abstraction to produce an alkyl site $\left(R^{\bullet}\right)$. This initiates a chain of reactions that can ultimately lead to the incorporation onto the surface of O-containing groups if the fluxes of O-containing species (e.g. $\mathrm{O}_{2}$ in an air discharge) are high enough. OH likely plays a similar role in initiating a series of reactions that enable $\mathrm{N}$-containing gas phase radicals to be incorporated as $\mathrm{N}$-containing groups onto the surface. Producing $\mathrm{N}$ atoms in air discharges is known to be difficult due to the large threshold

\begin{tabular}{|c|c|c|}
\hline Reactions $^{\mathrm{a}}$ & Rate coefficients ${ }^{\mathrm{b}}$ & References \\
\hline $\mathrm{O}+\mathrm{R}-\mathrm{H} \rightarrow \mathrm{R}^{\bullet}+\mathrm{OH}$ & $10^{-3}, 10^{-4}, 10^{-5}$ & {$[22]^{\mathrm{c}}$} \\
\hline $\mathrm{OH}+\mathrm{R}-\mathrm{H} \rightarrow \mathrm{R}^{\bullet}+\mathrm{H}_{2} \mathrm{O}$ & $0.25,0.05,0.0025$ & {$[22]^{\mathrm{c}}$} \\
\hline $\mathrm{H}+\mathrm{R}-\mathrm{H} \rightarrow \mathrm{R}^{\bullet}+\mathrm{H}_{2}$ & $10^{-5}, 10^{-6}, 10^{-7}$ & $\mathrm{c}, \mathrm{k}$ \\
\hline $\mathrm{He}^{+}+\mathrm{R}-\mathrm{H} \rightarrow \mathrm{R}^{\bullet}+\mathrm{H}+\mathrm{He}$ & 0.01 & [24] \\
\hline $\mathrm{NH}_{2}^{+}+\mathrm{R}-\mathrm{H} \rightarrow \mathrm{R}^{\bullet}+\mathrm{H}+\mathrm{NH}_{2}$ & 0.01 & [24] \\
\hline $\mathrm{NH}^{+}+\mathrm{R}-\mathrm{H} \rightarrow \mathrm{R}^{\bullet}+\mathrm{H}+\mathrm{NH}$ & 0.01 & [24] \\
\hline$h v+\mathrm{R}-\mathrm{H} \rightarrow \mathrm{R} \cdot+\mathrm{H}$ & 0.2 & {$[23,25]^{\mathrm{d}}$} \\
\hline$h v+\mathrm{R}-\mathrm{H} \rightarrow \bullet^{\bullet}+\mathrm{H}_{2}$ & 0.2 & {$[23,25]^{\mathrm{d}}$} \\
\hline$h v+\mathrm{R}-\mathrm{H} \rightarrow \mathrm{R}^{\bullet}+\mathrm{CH}_{3}$ & 0.2 & {$[23,25]^{\mathrm{d}}$} \\
\hline $\mathrm{R}-\mathrm{H}+\mathrm{N} \rightarrow \mathrm{R}-\mathrm{NH}$ & $10^{-2}$ & e \\
\hline $\mathrm{R}-\mathrm{H}+\mathrm{NH} \rightarrow \mathrm{R}-\mathrm{NH}_{2}$ & $10^{-5}$ & f \\
\hline $\mathrm{R}^{\bullet}+\mathrm{N} \rightarrow \mathrm{R}=\mathrm{NH}$ & 0.4 & $\mathrm{e}$ \\
\hline $\mathrm{R}^{\bullet}+\mathrm{NH} \rightarrow \bullet \mathrm{R}-\mathrm{NH}$ & 0.4 & $\mathrm{~g}$ \\
\hline $\mathrm{R}^{\bullet}+\mathrm{NH}_{2} \rightarrow \mathrm{R}-\mathrm{NH}_{2}$ & 0.4 & {$[20,21]^{\mathrm{h}}$} \\
\hline $\mathrm{R}-\mathrm{NH}+\mathrm{H} \rightarrow \mathrm{R}-\mathrm{NH}_{2}$ & 0.2 & $\mathrm{i}$ \\
\hline $\mathrm{R}-\mathrm{NH}+\mathrm{H} \rightarrow \mathrm{R}=\mathrm{NH}+\mathrm{H}_{2}$ & $10^{-6}$ & $\mathrm{j}$ \\
\hline $\mathrm{R}-\mathrm{NH}_{2}+\mathrm{H} \rightarrow \mathrm{R}-\mathrm{NH}+\mathrm{H}_{2}$ & $10^{-6}$ & $\mathrm{k}$ \\
\hline $\mathrm{R}-\mathrm{NH}_{2}+\mathrm{OH} \rightarrow \mathrm{R}-\mathrm{NH}+\mathrm{H}_{2} \mathrm{O}$ & 0.0025 & $\mathrm{k}$ \\
\hline $\mathrm{R}=\mathrm{NH}+\mathrm{H} \rightarrow \mathrm{R}-\mathrm{NH}_{2}$ & $10^{-5}$ & h \\
\hline $\mathrm{H}+\mathrm{R}^{\bullet} \rightarrow \mathrm{R}-\mathrm{H}$ & 0.2 & [22] \\
\hline $\mathrm{OH}+\mathrm{R}^{\bullet} \rightarrow \mathrm{R}-\mathrm{OH}$ & 0.2 & [22] \\
\hline
\end{tabular}
energy and small cross section for electron impact dissociation of $\mathrm{N}_{2}$. In contrast, $\mathrm{N}$-containing radicals (e.g. $\mathrm{NH}_{x}$ fragments) can be created in abundance in ammonia containing discharges due to the lower threshold energy and larger cross sections. As such, we chose $\mathrm{He} / \mathrm{NH}_{3} / \mathrm{H}_{2} \mathrm{O}$ to be the gas mixture for this study.

The absence of $\mathrm{O}_{2}$ as a feedstock in $\mathrm{He} / \mathrm{NH}_{3} / \mathrm{H}_{2} \mathrm{O}$ mixtures has the added benefit of eliminating direct $\mathrm{O}_{2}$ incorporation to form peroxy groups $\left(\mathrm{R}-\mathrm{OO}^{*}\right)$ on the surface by the passivation
Table 1. Surface reaction mechanism for $\mathrm{PP}$ in $\mathrm{He} / \mathrm{NH}_{3} / \mathrm{H}_{2} \mathrm{O}$ discharges.

${ }^{a} \mathrm{R}-\mathrm{H}$ denotes a saturated PP site.

${ }^{\mathrm{b}}$ Coefficients are reaction probabilities.

${ }^{\mathrm{c}}$ For tertiary, secondary and primary carbon centers, respectively.

${ }^{\mathrm{d}}$ Pathways described in [25] for energetic photons; quantum yield estimate from [23].

${ }^{\mathrm{e}}$ Insertion analogous to gas phase reaction in [19] followed by double bond formation.

${ }^{\mathrm{f}}$ Insertion analogous to gas phase reaction in [18]

${ }^{\mathrm{g}}$ By analogy to $\mathrm{NH}_{2}$.

${ }^{\mathrm{h}}$ By analogy to gas phase reactions.

${ }^{\mathrm{i}}$ By analogy to reactions with alkyl radicals in [22].

${ }^{j}$ Proposed abstraction of $\mathrm{H}$ followed by double bond formation.

${ }^{\mathrm{k}}$ By analogy to reactions with alkanes in [20].

of alkyl sites $\left(\mathrm{R}^{\bullet}\right)$. Having said that, it is acknowledged that in most situations, it is difficult to completely eliminate $\mathrm{O}_{2}$ contamination of the gas mixture at atmospheric pressure. Since the passivation of alkyl sites by $\mathrm{O}_{2}$ is a rapid process, some unwanted O-incorporation will likely occur even if the intent is to eliminate such processes by purposely not having $\mathrm{O}_{2}$ as a feedstock. Although incorporation of $\mathrm{O}$ into the film is accounted for by O-containing fluxes that might naturally occur in the $\mathrm{He} / \mathrm{NH}_{3} / \mathrm{H}_{2} \mathrm{O}$ mixture, we did not explicitly account for $\mathrm{O}_{2}$ contamination of the feedstock gases.

The reaction probabilities leading to affixing $\mathrm{NH}_{x}$ to the PP surface have not been as exhaustively investigated as has been for O-functionalization, though probable pathways have been proposed from experimental observations [17]. Our interest is in affixing amine $\left(\mathrm{R}-\mathrm{NH}_{2}\right)$, amino radical $(\cdot \mathrm{R}-\mathrm{NH})$ and imine $(\mathrm{R}=\mathrm{NH})$ groups. As such, a set of hierarchical reactions for $\mathrm{N}$-functionalization has been proposed similar to that for O-functionalization [15] and are summarized in table 1.

$\mathrm{N}$-containing groups can be formed by either direct insertion of $\mathrm{N}$-containing species into the backbone $\mathrm{C}-\mathrm{H}$ bonds or by addition to a free radical site, $\mathrm{R}^{\bullet}$. By analogy to gas phase reactions, the direct insertion of $\mathrm{N}$ or $\mathrm{NH}$ into the hydrocarbon backbone likely has a low probability given 
the large endothermicity of such processes. For example, the insertion of $\mathrm{NH}$ radicals into $\mathrm{R}-\mathrm{H}$,

$$
\mathrm{RH}+\mathrm{NH} \rightarrow \mathrm{R}-\mathrm{NH}_{2},
$$

has an estimated probability of $10^{-5}$ based on analogous insertion of $\mathrm{NH}$ into gas phase alkanes which has a room temperature rate coefficient of $<10^{-15} \mathrm{~cm}^{3} \mathrm{~s}^{-1}$ [18]. Excited $\mathrm{N}$ atoms $\left(\mathrm{N}^{*}\right)$ may directly insert into the $\mathrm{C}-\mathrm{H}$ bonds of alkanes in the gas phase at rate coefficients of $10^{-12} \mathrm{~cm}^{3} \mathrm{~s}^{-1}$ [19] but the density of $\mathrm{N}^{*}$ is typically low $\left(<10^{9} \mathrm{~cm}^{-3}\right.$ in humid air atmospheric pressure discharges [15]), so this pathway is not expected to be important.

The addition of $\mathrm{N}$-containing groups to the hydrocarbon backbone likely proceeds through a multi-step process in which $\mathrm{H}$ is first abstracted from the backbone creating an alkyl surface radical, $\mathrm{R}^{\bullet}$, followed by passivation of the surface radical by $\mathrm{N}, \mathrm{NH}$ or $\mathrm{NH}_{2}$. In oxygen containing atmospheric pressure discharges, such as in air, $\mathrm{O}$ atoms typically abstract $\mathrm{H}$ from the backbone followed by passivation of the resulting alkyl $\left(\mathrm{R}^{\bullet}\right)$ site by $\mathrm{O}_{2}$ to form a peroxy (R-OO•). In affixing amine groups, it is not desirable to also affix O. So the initiating abstraction reaction should be by a radical whose parent molecule does not produce unwanted passivation of the resulting radical site. For example, $\mathrm{H}$ abstraction by $\mathrm{O}$ produced by electron impact of $\mathrm{O}_{2}$ might be followed by passivation of the radical site by $\mathrm{O}_{2}$, which is not desirable. As such, $\mathrm{O}_{2}$ should not be used in the gas mixture. Instead, we propose using small admixtures of water vapor to initiate the affixation process. $\mathrm{H}$ is abstracted from $\mathrm{RH}$ by $\mathrm{OH}$ which is produced by electron impact dissociation of $\mathrm{H}_{2} \mathrm{O}$,

$$
\mathrm{RH}+\mathrm{OH} \rightarrow \mathrm{R}^{\bullet}+\mathrm{H}_{2} \mathrm{O} .
$$

The abstraction probability by $\mathrm{OH}$ is large, $\approx 0.1$. As such, large densities of $\mathrm{OH}$ are not required for significant alkyl surface radical production which then minimizes the probability that $\mathrm{OH}$ will passivate the $\mathrm{R}^{\bullet}$ sites and affix $\mathrm{OH}$ to form alcohol groups. As the same time, $\mathrm{H}_{2} \mathrm{O}$ is relatively unreactive with these alkyl sites and does not affix oxygen. At worst, alkyl sites may be re-passivated with $\mathrm{H}$ atoms.

The gas phase reactions of $\mathrm{H}$ and $\mathrm{OH}$ with $\mathrm{C}_{4} \mathrm{H}_{10}$ [20] were used as references to determine the relative reactivities of $\mathrm{H}$ and $\mathrm{OH}$ for $\mathrm{H}$ abstraction from the $\mathrm{RH}$ backbone. The probability for $\mathrm{H}$ abstraction from $\mathrm{RH}$ by $\mathrm{H}$ atoms is a factor of $10^{-3}-10^{-5}$ smaller than that for $\mathrm{OH}$ depending on whether the carbon site on the PP chain is the primary, secondary or tertiary carbon center. However, since the density of $\mathrm{H}$ in $\mathrm{NH}_{3}$ containing discharges can be large due to the efficient electron impact dissociation of $\mathrm{NH}_{3}$, the contribution of $\mathrm{H}$ atoms to $\mathrm{H}$ abstraction becomes significant. The assigned absolute probability for $\mathrm{H}$ atoms to abstract $\mathrm{H}$ from $\mathrm{RH}$ is $10^{-5}$ for tertiary carbon atoms and decreasing one order of magnitude for secondary and primary carbon atoms.

The possibility of $\mathrm{NH}$ and $\mathrm{NH}_{2}$ abstracting $\mathrm{H}$ from the hydrocarbon backbone was also considered. The analogous gas phase rate coefficients for abstraction of $\mathrm{H}$ atoms by $\mathrm{NH}$ and $\mathrm{NH}_{2}$ with $\mathrm{C}_{n} \mathrm{H}_{2 n+2}$ for various $n$ are small relative to that by $\mathrm{OH}$ (by a factor of approximately $10^{-6}$ ). As a result, absolute probabilities for these reactions are small enough that they were not included in the mechanism.

Further $\mathrm{H}$ abstraction from sites adjacent to $\mathrm{R}^{\bullet}$ can lead to double bonding $(\mathrm{R}=\mathrm{R})$ on the surface. Addition reactions across this double bond would reform $\mathrm{R} \bullet$ sites,

$$
\begin{gathered}
\mathrm{R}^{\bullet}+\mathrm{H} \rightarrow \mathrm{R}=\mathrm{R}+\mathrm{H}_{2}, \\
\mathrm{R}=\mathrm{R}+X \rightarrow \mathrm{R}-X+\mathrm{R}^{\bullet} \quad\left(X=\mathrm{NH}, \mathrm{NH}_{2}\right) .
\end{gathered}
$$

Amine groups $\left(\mathrm{R}-\mathrm{NH}_{2}\right)$ are dominantly formed on the PP surface by the addition of $\mathrm{NH}_{2}$ and to $\mathrm{R}^{\bullet}$ radicals.

$$
\mathrm{R}^{\bullet}+Y \rightarrow \mathrm{R}-Y \quad\left(Y=\mathrm{NH}, \mathrm{NH}_{2}\right) .
$$

The analogous gas phase rate coefficient for reaction of $\mathrm{NH}_{2}$ with alkyl radicals is about $4 \times 10^{-11} \mathrm{~cm}^{3} \mathrm{~s}^{-1}$ [21], so a probability of 0.4 is used for the corresponding surface reaction. The addition of $\mathrm{NH}$ was assigned a probability of 0.4 by analogy to $\mathrm{NH}_{2}$.

$\mathrm{H}$ abstraction from $\mathrm{R}-\mathrm{NH}_{2}$ groups by $\mathrm{H}$ and $\mathrm{OH}$ form $\mathrm{R}-\mathrm{NH}$ groups, which can again react with gas phase $\mathrm{H}$ atoms to reform $\mathrm{R}-\mathrm{NH}_{2}$,

$$
\begin{gathered}
\mathrm{R}-\mathrm{NH}_{2}+\mathrm{OH} \rightarrow \mathrm{R}-\mathrm{NH}+\mathrm{H}_{2} \mathrm{O}, \\
\mathrm{R}-\mathrm{NH}_{2}+\mathrm{H} \rightarrow \mathrm{R}-\mathrm{NH}+\mathrm{H}_{2}, \\
\mathrm{R}-\mathrm{NH}+\mathrm{H} \rightarrow \mathrm{R}-\mathrm{NH}_{2} .
\end{gathered}
$$

The probabilities for these abstraction and addition reactions were taken to be similar to $\mathrm{H}$ abstraction from $\mathrm{C}-\mathrm{H}$ bonds and addition to $\mathrm{R}^{\cdot}$ radicals. $\mathrm{H}$ abstraction at the carbon centers of primary and secondary $\mathrm{R}-\mathrm{NH}$ sites could lead to the formation of imines $(\mathrm{R}=\mathrm{NH})$,

$$
\begin{gathered}
\mathrm{R}-\mathrm{NH}+\mathrm{H}, \rightarrow \mathrm{R}-\mathrm{NH}+\mathrm{H}_{2} \rightarrow \mathrm{R}=\mathrm{NH}, \\
\mathrm{R}-\mathrm{NH}+\mathrm{OH} \rightarrow \mathrm{R}-\mathrm{NH}+\mathrm{H}_{2} \mathrm{O} \rightarrow \mathrm{R}=\mathrm{NH} .
\end{gathered}
$$

\section{Functionalization of rough surfaces in $\mathrm{He} / \mathrm{NH}_{3} / \mathrm{H}_{2} \mathrm{O}$ discharges}

The plasma functionalization of PP with surfaces having roughness with scale lengths of a few micrometers was investigated in atmospheric pressure corona discharges. The device is the same as that investigated in part I [15] and a schematic appears in figure 1 of part I. The top electrode is surrounded by a dielectric and exposed to gas at its tip. The gap between the upper and the lower grounded electrode is $2 \mathrm{~mm}$. The PP is on the lower electrode, so the device effectively operates as a dielectric-barrier discharge. Roughness on the polymer surface is resolved having strand-like features of a few micrometers scale length to resemble textile or scaffolding-like surfaces for cell-adhesion, as shown in the same figure. An unstructured mesh with multiple refinement zones is overlaid on the geometry to resolve both the reactor-scale and surfacescale processes.

As explained in part I, during the discharge pulse (usually $<10 \mathrm{~ns}$ ), charged particle transport (including solution of Poisson's equation), neutral transport and surface kinetics are 


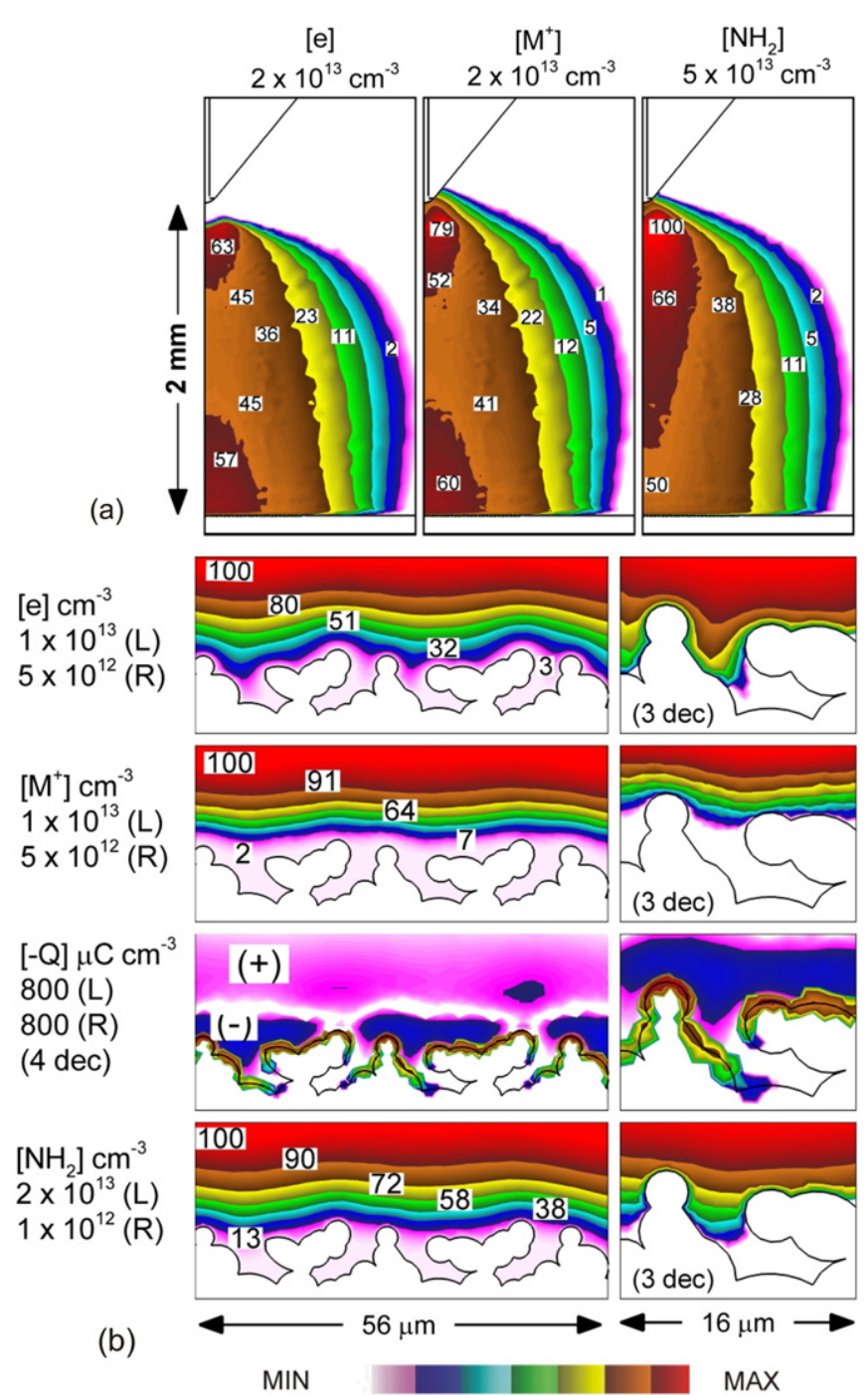

Figure 1. Plasma properties after the first discharge pulse in a $1 \mathrm{~atm}$, $\mathrm{He} / \mathrm{NH}_{3} / \mathrm{H}_{2} \mathrm{O}=98 / 1 / 1$ mixture with a $-5 \mathrm{kV}$ potential. (a) Electron, total ion and $\mathrm{NH}_{2}$ densities. (b) Electron, total ion, charge and $\mathrm{NH}_{2}$ densities in the vicinity of the surface. The contour labels are percentages of the maximum density noted in each figure. In $(b)$, $\mathrm{L}$ and $\mathrm{R}$ denote the left and right figures.

solved for. During the IP, only the neutral chemistry and transport and surface kinetics are solved. After the IP, the discharge is reinitiated. This procedure is continued until quasi-steady state conditions are achieved. At this point, the time-varying fluxes of all plasma species at all locations on the polymer surface are recorded for one more pulse and IP. These recorded fluxes are then interpolated as a function of time while executing the surface kinetics module for additional pulses and interpulse periods. In the following discussion on uniformity of treatment, macroscopic refers to scale lengths of the discharge, up to a few millimeters; whereas microscopic refers to lengths on the order of the surface features, up to tens of micrometers.

The base case conditions are atmospheric pressure, gas composition of $\mathrm{He} / \mathrm{NH}_{3} / \mathrm{H}_{2} \mathrm{O}=98 / 1 / 1$ and applied potential of $-5 \mathrm{kV}$ at $10 \mathrm{kHz}$, so the IP is about $100 \mu \mathrm{s}$. Typical conditions at the end of the discharge pulse for the base case are shown in figure 1 . The avalanche produces an electron density of $10^{13} \mathrm{~cm}^{-3}$ in the bulk plasma. Unlike corona discharges in air, attachment is not particularly important in this gas mixture and so the positive ion density is essentially the same as the electron density. $\mathrm{NH}_{3}$ is efficiently dissociated by electron impact producing a density of $\mathrm{NH}_{2}$ and $\mathrm{H}$ atoms of about $5 \times 10^{13} \mathrm{~cm}^{-3}$ after the pulse. The dissociation of $\mathrm{H}_{2} \mathrm{O}$ produces $\mathrm{OH}$ densities of $1.5 \times 10^{11} \mathrm{~cm}^{-3}$ near the cathode and $6 \times 10^{11} \mathrm{~cm}^{-3}$ near the surface. The spatial extent of the discharge is broader than the humid air discharges discussed in Part I due to the smaller rates of momentum transfer and longer mean free path for energy loss in this gas mixture.

Plasma properties near the surface features after the first pulse are shown in figure $1(b)$. In this negative corona discharge, electrons lead the quasi-neutral plasma in the avalanche front. The avalanche leading electrons are in a non-neutral region many micrometers in extent. Since the polymer covers the anode, these electrons initially penetrate into the surface features to a limited extent negatively charging the PP surface (to a maximum density of $100 \mu \mathrm{C} \mathrm{cm}^{-3}$ ). As the surface charges to the local plasma potential, further penetratation by electrons is retarded to balance the limited penetration of positive ions. The relative lack of plasma inside the surface features results in little electron impact dissociation inside features and so a large gradient in radical densities. For example, just after the pulse $\mathrm{NH}_{2}$ has been generated in the immediate vicinity of the features by electron impact dissociation of $\mathrm{NH}_{3}$ to a density of $2 \times 10^{13} \mathrm{~cm}^{-3}$, but is almost absent inside the features.

The densities of $\mathrm{OH}, \mathrm{H}$ and $\mathrm{NH}_{2}$ radicals in the bulk and near the surface features at the end of the first IP are shown in figure 2. By this time, $\mathrm{OH}$ is depleted by gas phase reactions and diffusion, having a peak density of $6 \times 10^{11} \mathrm{~cm}^{-3}$ in the center of the discharge. Abstraction reactions with the surface additionally deplete the $\mathrm{OH}$ density near the features to about $10^{10} \mathrm{~cm}^{-3}$. (Recall from part I that the microstructure in the meshes extends only $600 \mu \mathrm{m}$ from the axis. The more severe gradients in $\mathrm{OH}$ over that region results from the larger surface area of the microstructure compared with the flat surface further off-axis.) By the end of the IP, the density of $\mathrm{NH}_{2}$ decreases by a factor of 10 due to association reactions to form $\mathrm{N}_{2} \mathrm{H}_{4}$, while the density of $\mathrm{H}$ atoms remains at $10^{13} \mathrm{~cm}^{-3}$. In the vicinity of the surface, the densities of $\mathrm{H}, \mathrm{NH}_{2}$ and $\mathrm{N}_{2} \mathrm{H}_{2}$ have small spatial gradients on the scale of the roughness due to their low reactivity with the surface. In contrast, $\mathrm{OH}$ radicals continue to react with the surface during the entire IP and so larger gradients in $\mathrm{OH}$ density into the microstructure occur.

The fluxes of $\mathrm{H}, \mathrm{NH}_{2}$ and $\mathrm{OH}$ averaged over the interpulse period are shown in figure 3( $a$ ) as a function of position along the surface. (The surface position is the integral path along the surface going into and out of features, and so is longer than the lateral dimension of the surface.) There is little macroscopic non-uniformity over a few millimeters from the axis due to the initially broad discharge and rapid subsequent diffusion in the He dominated gas mixture. There is significant microscopic structure in the flux of $\mathrm{OH}$. Sites with large view angles to the plasma receive fluxes of about $10^{16} \mathrm{~cm}^{-2} \mathrm{~s}^{-1}$ or about 10 times the flux received by the shadowed sites. Since $\mathrm{OH}$ is highly reactive with the surface, and the local surface 


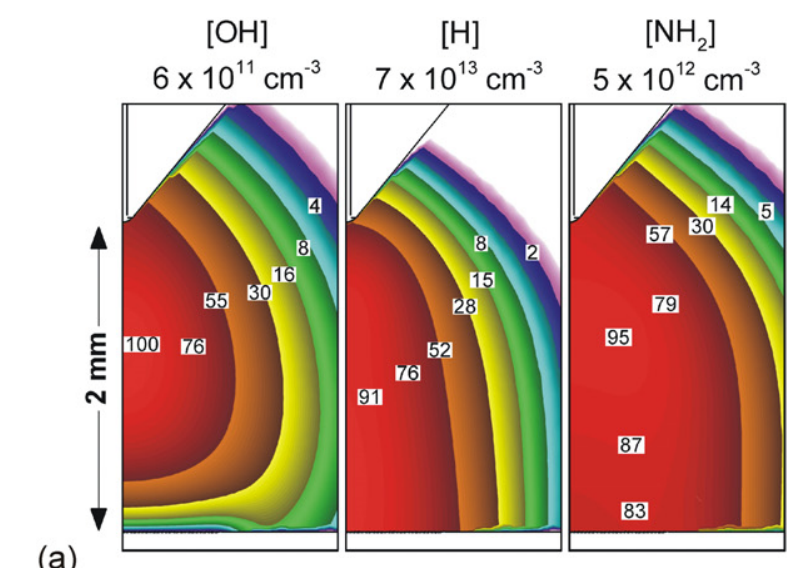

(a)
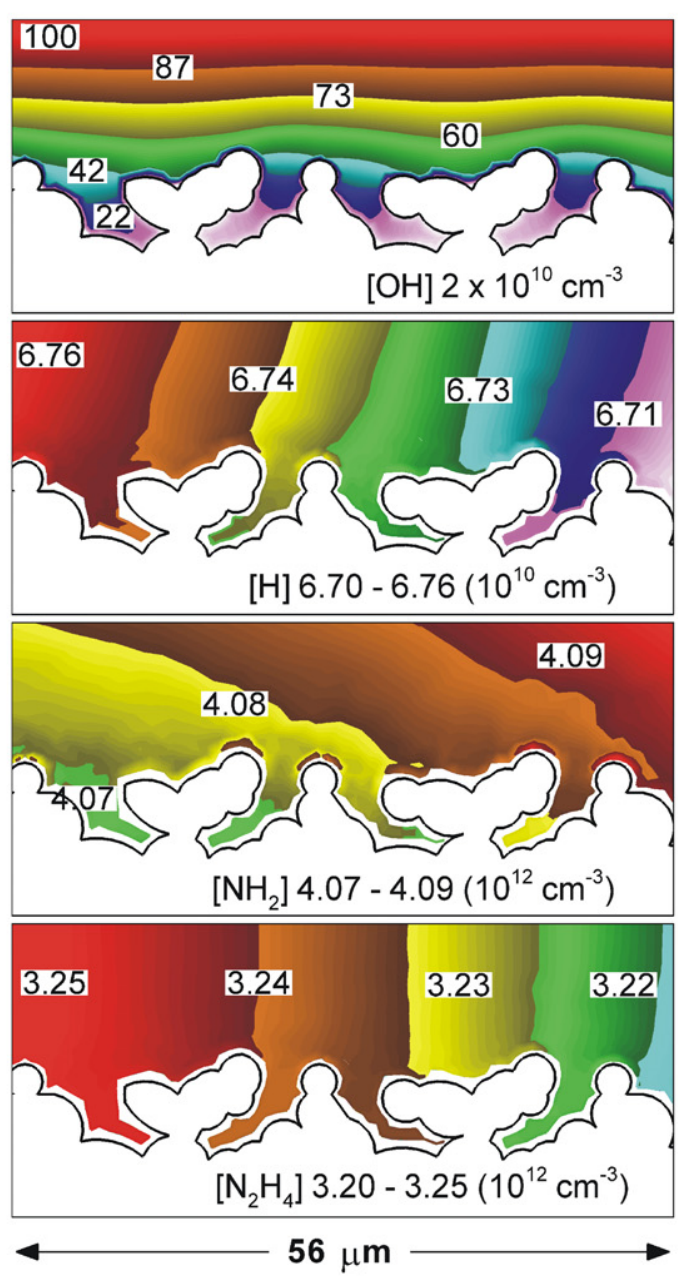

MIN

MAX

Figure 2. Plasma properties after the first interpulse period (100 $\mu \mathrm{s})$ in a $1 \mathrm{~atm}, \mathrm{He} / \mathrm{NH}_{3} / \mathrm{H}_{2} \mathrm{O}=98 / 1 / 1$ mixture. (a) $\mathrm{OH}, \mathrm{H}$ and $\mathrm{NH}_{2}$ densities. (b) $\mathrm{OH}, \mathrm{H}, \mathrm{NH}_{2}$ and $\mathrm{N}_{2} \mathrm{H}_{4}$ densities in the vicinity of the surface. The contour labels are percentages of the maximum density noted in each figure. For $\mathrm{H}, \mathrm{NH}_{2}$ and $\mathrm{N}_{2} \mathrm{H}_{4}$ in $(b)$, the labels are actual values.

kinetics dominate during the IP, $\mathrm{OH}$ is depleted as it diffuses into the features. There is little microscopic structure in the fluxes of $\mathrm{H}$ and $\mathrm{NH}_{2}$ other than the shadowing effect of the surface features. This is due to the lower surface reactivity of $\mathrm{H}$ and $\mathrm{NH}_{2}$ which enables diffusion to smooth out their gradients.
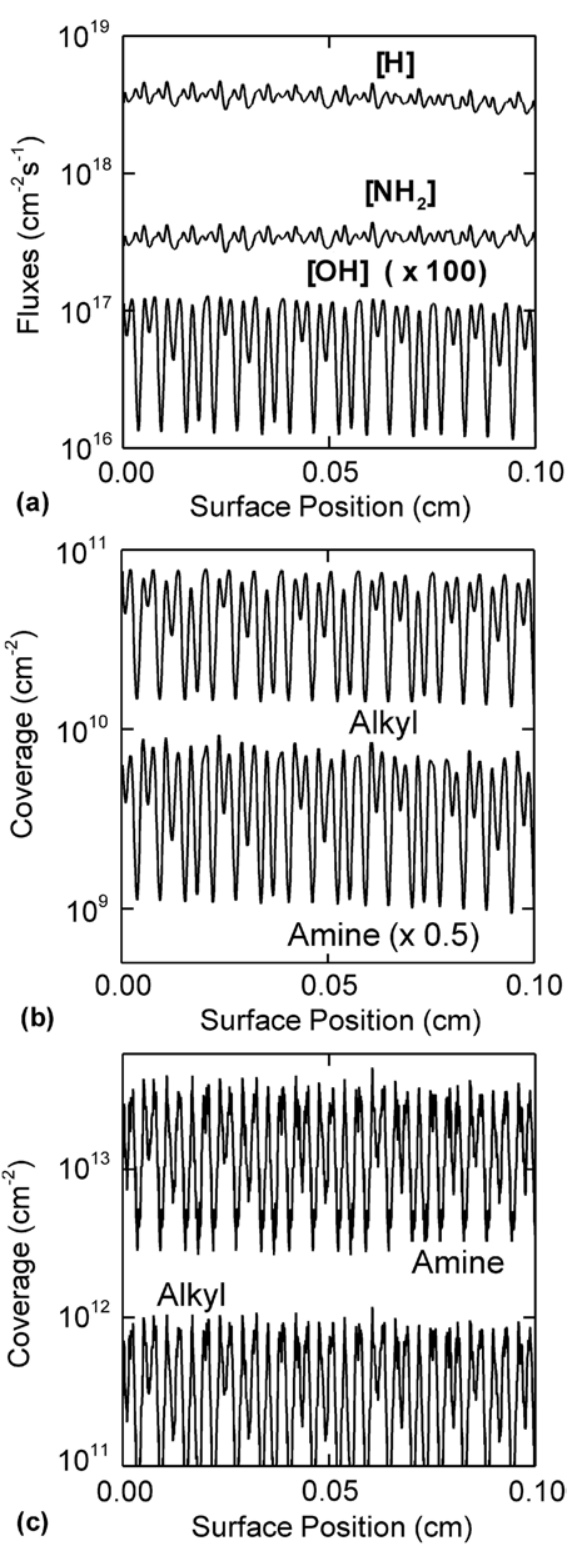

Figure 3. Plasma and surface properties for the conditions of figure 2. (a) $\mathrm{H}, \mathrm{OH}$ and $\mathrm{NH}_{2}$ fluxes to the surface averaged over the interpulse period. The coverage of alkyl and amine groups after $(b)$ the first interpulse period and $(c)$ after $0.1 \mathrm{~s}$ of treatment.

The coverages of alkyl $\left(\mathrm{R}^{\bullet}\right)$ radicals and amine $\left(\mathrm{R}-\mathrm{NH}_{2}\right)$ groups after $100 \mu \mathrm{s}$ (the first IP) are shown in figure 3(b). (Full surface coverage is $10^{15} \mathrm{~cm}^{-2}$.) Since $\mathrm{OH}$ radicals are primarily responsible for $\mathrm{H}$ abstraction, the microscopic variations in $\mathrm{OH}$ fluxes are mirrored into the coverages of alkyl $\left(\mathrm{R}^{*}\right)$ radicals. Upon passivation of these sites with $\mathrm{NH}_{2}$, the $\mathrm{R}-\mathrm{NH}_{2}$ coverage then also has significant microscopic nonuniformity. The coverage of amine radicals $\left(\mathrm{R}-\mathrm{NH}^{*}\right)$ is about $10^{-1}$ that of the amine and that of imine $(\mathrm{R}=\mathrm{NH})$ groups is $10^{-3}$. The alkyl and amine coverages after $0.1 \mathrm{~s}$ of treatment are shown in figure $3(c)$. The alkyl $\left(\mathrm{R}^{\bullet}\right)$ sites are created and passivated during each IP and achieve a near steady-state coverage of a few $10^{11} \mathrm{~cm}^{-2}$. On the other hand, the amine $\left(\mathrm{R}-\mathrm{NH}_{2}\right)$ sites are relatively unreactive once formed and so accumulate from pulse to pulse reaching about $5 \%$ coverage after 1000 pulses. 

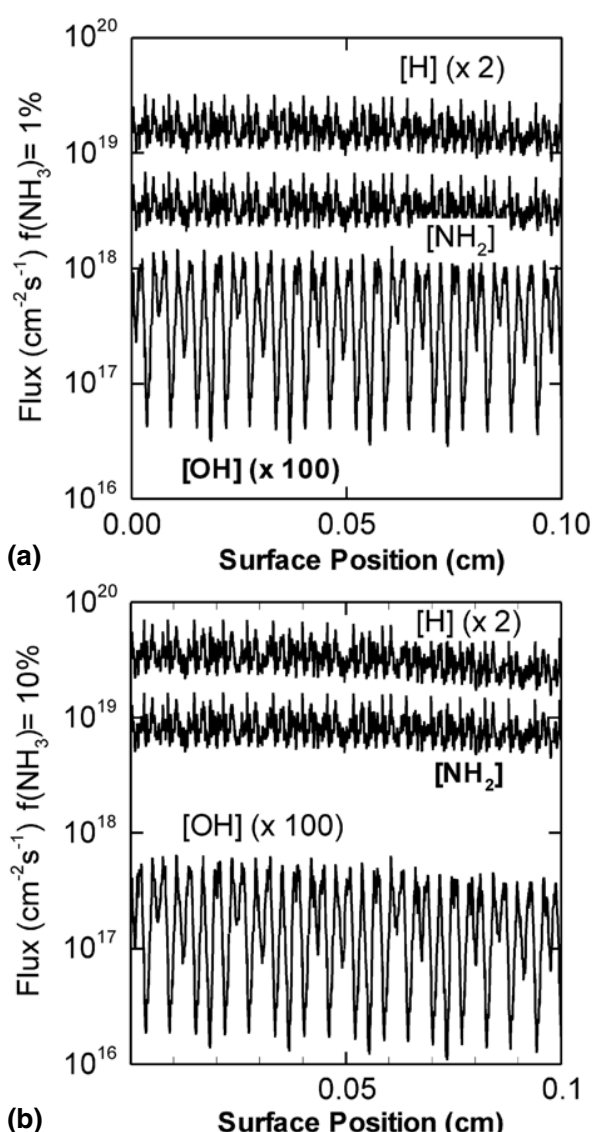

(b) Surface Position (cm)

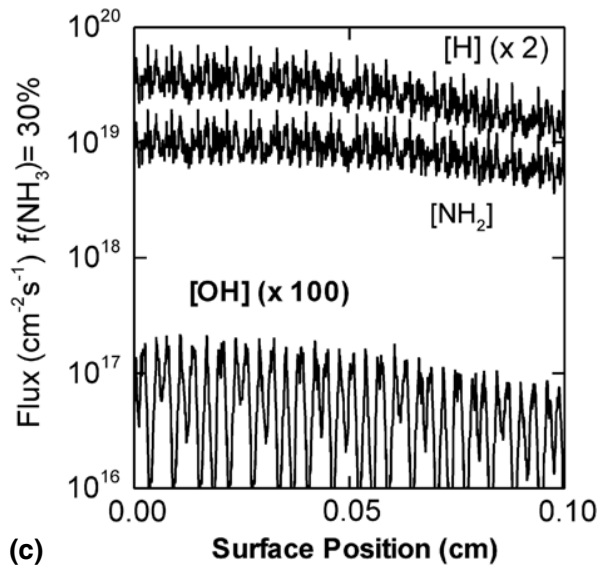

Figure 4. $\mathrm{H}, \mathrm{OH}$ and $\mathrm{NH}_{2}$ fluxes to the rough surface averaged over the interpulse period for different fractions of $\mathrm{NH}_{3}$ in a

$\mathrm{He} / \mathrm{NH}_{3} / \mathrm{H}_{2} \mathrm{O}=99-x / x / 1$ mixture. (a) $1 \%$, (b) $10 \%$ and (c) $30 \%$. Conditions are otherwise similar to those for figure 1 .

The fraction of $\mathrm{NH}_{3}$ in the discharge, $f\left(\mathrm{NH}_{3}\right)$, was varied while keeping the fraction of $\mathrm{H}_{2} \mathrm{O}$ constant at $1 \%$ and other conditions unchanged from the base case. The time averaged fluxes of $\mathrm{H}, \mathrm{NH}_{2}$ and $\mathrm{OH}$ to the surface for $f\left(\mathrm{NH}_{3}\right)$ of $1 \%, 10 \%$ and $30 \%$ are shown in figure 4 . When increasing $f\left(\mathrm{NH}_{3}\right)$ from $1 \%$ to $30 \%$, the flux of $\mathrm{NH}_{2}$ increases by only a factor of 3 , which indicates that the production of $\mathrm{NH}_{2}$ is energy limited and not due to depletion of $\mathrm{NH}_{3}$. The magnitude of $\mathrm{OH}$ fluxes decreases by a factor of nearly 10 as $f\left(\mathrm{NH}_{3}\right)$ increases from $1 \%$ to $30 \%$. This is because more electron energy is dissipated in $\mathrm{NH}_{3}$ vibrational and electronic excitation as $f\left(\mathrm{NH}_{3}\right)$ increases, and so less energy is channeled into dissociative reactions of
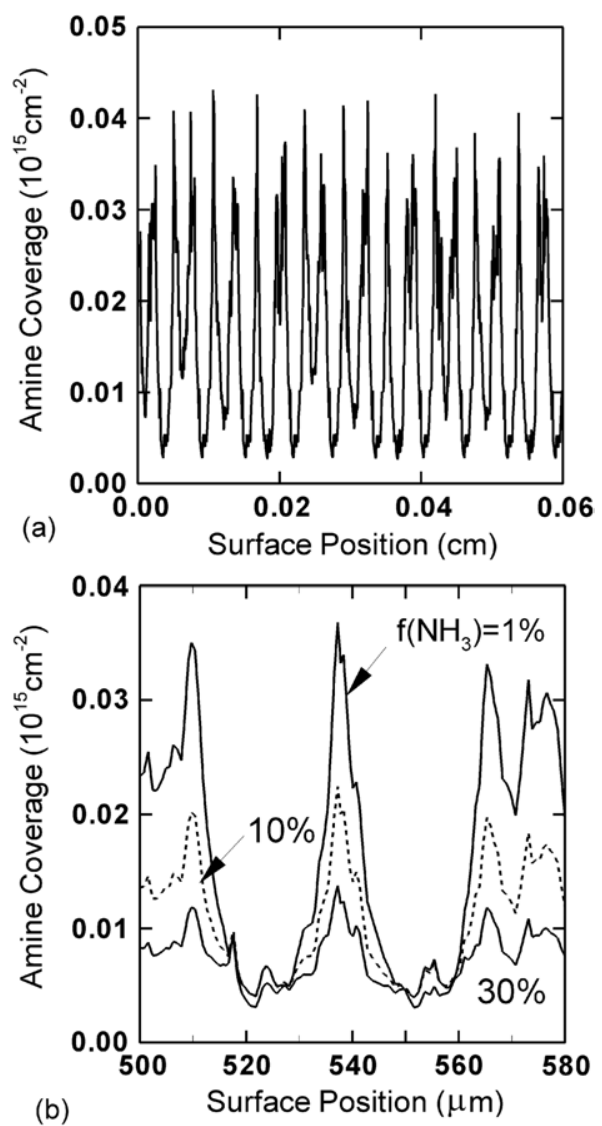

Figure 5. Surface coverage of amine groups for $\mathrm{He} / \mathrm{NH}_{3} / \mathrm{H}_{2} \mathrm{O}$ discharges. (a) $1 \% \mathrm{NH}_{3}$ fraction and $(b)$ magnified view for $1 \%$, $10 \%$ and $30 \% \mathrm{NH}_{3}$.

$\mathrm{H}_{2} \mathrm{O}$ creating $\mathrm{OH}$ radicals. The microscopic uniformities in all fluxes are not sensitive functions of $f\left(\mathrm{NH}_{3}\right)$ as these are determined by the relative surface reactivity of the fluxes and the local microstructure.

The coverage of amine groups $\left(\mathrm{R}-\mathrm{NH}_{2}\right)$ for $f\left(\mathrm{NH}_{3}\right)=$ $1 \%$ after $1 \mathrm{~s}$ of treatment is shown in figure $5(a)$. The coverage is expanded around a few surface features in figure $5(b)$. The maximum coverage of $\mathrm{R}-\mathrm{NH}_{2}$ on the surface sites with large view angles to the plasma approaches $4 \%$ but is less than $0.5 \%$ in the shadowed regions. This results from the cumulative effect over thousands of pulses of $\mathrm{OH}$ fluxes being depleted as they diffuse into the surface features. The dynamic range in amine coverage (from exposed sites to hidden sites) decreases with treatment time as PP sites at exposed features are saturated and become less reactive to $\mathrm{OH}$. This enables $\mathrm{OH}$ to penetrate further into the microstructure. The maximum coverage of $\mathrm{R}-\mathrm{NH}_{2}$ on the vertices of the surface features decreases from $3 \%$ to $1 \%$ as $f\left(\mathrm{NH}_{3}\right)$ increases from $1 \%$ to $30 \%$. This results from the decrease in $\mathrm{OH}$ fluxes as $f\left(\mathrm{NH}_{3}\right)$ increases and the process not being rate limited by the availability of $\mathrm{NH}_{2}$. The amine coverage is nearly insensitive to $f\left(\mathrm{NH}_{3}\right)$ inside the features, resulting in microscopic uniformity increasing with increasing $f\left(\mathrm{NH}_{3}\right)$. In this case, it is the creation of initiating alkyl $\left(\mathrm{R}^{\bullet}\right)$ sites that is the rate limiting step.

In $\mathrm{He} / \mathrm{NH}_{3} / \mathrm{H}_{2} \mathrm{O}$ discharges, the uniformity of amine $\left(\mathrm{R}-\mathrm{NH}_{2}\right)$ is ultimately dependent on the availability of alkyl sites and the propensity of $\mathrm{NH}_{x}$ radicals to passivate those 
sites. The coverage of $\mathrm{R}^{\cdot}$ sites is in turn determined in part by $f\left(\mathrm{H}_{2} \mathrm{O}\right)$ since $\mathrm{OH}$ radicals are the dominant $\mathrm{H}$ abstracting species. The high reactivity of $\mathrm{OH}$ at the sites at the vertices and at the opening of features depletes $\mathrm{OH}$ fluxes into the nooks and crannies. This creates non-uniformities in moderately treated materials, with as large as a factor of 10 in $\mathrm{R}^{\cdot}$ and $\mathrm{R}-\mathrm{NH}_{2}$ coverages between exposed features and nooks and crannies. As $f\left(\mathrm{NH}_{3}\right)$ increases, more electron energy is spent in dissociating $\mathrm{NH}_{3}$, leading to higher $\mathrm{NH}_{2}$ fluxes but lower $\mathrm{OH}$ fluxes. As a result, the abstraction reactions become rate-limiting and the coverage of $\mathrm{R}-\mathrm{NH}_{2}$ decreases at higher $f\left(\mathrm{NH}_{3}\right)$.

\section{Functionalization of porous micro-beads in $\mathrm{He} / \mathrm{NH}_{3} / \mathrm{H}_{2} \mathrm{O}$ discharges}

Porous polymer micro-beads are being investigated in biomedical arenas for drug delivery and viral therapy applications. It is often the case that the external and internal surfaces of these beads are functionalized to provide the desired biocompatibility. This is typically an expensive process. Functionalizing the surfaces with an inexpensive atmospheric pressure discharge might be a desirable alternative. The ability of atmospheric pressure discharges to perform this functionalization was investigated using idealized porous PP beads with diameters of tens of micrometers and internal porosity with openings and channel sizes of a few micrometers. Using the corona discharge described above, beads were either placed on a grounded substrate or suspended in the discharge (see figure 6), as might occur if the beads were blown through the gap.

The base case consists of a $\mathrm{He} / \mathrm{NH}_{3} / \mathrm{H}_{2} \mathrm{O}=98 / 1 / 1$ mixture at $1 \mathrm{~atm}$ with $-5 \mathrm{kV}$ discharge pulses of negligible rise and fall time $10 \mathrm{~ns}$ in duration. Two identical porous microbeads $90 \mu \mathrm{m}$ in diameter having pore diameters of $4 \mu \mathrm{m}$ are on the grounded metal substrate. One bead is on the centerline and the other is $270 \mu \mathrm{m}$ off-axis (figure $6(a)$ ). The plasma density after the first discharge pulse is shown in figure 7 . The electron and total positive ion densities are about $10^{13}-10^{14} \mathrm{~cm}^{-3}$ in the ionized channel with the maximum densities near the cathode and the micro-beads on the surface. $\mathrm{NH}_{2}$ densities, also shown in figure 7, approach $10^{16} \mathrm{~cm}^{-3}$. These densities are almost an order of magnitude larger than when the device is operated as a dielectric-barrier discharge (lower electrode covered by PP) since the current is not limited by the capacitance of the barrier.

The electron, positive ion and charge densities around the offset micro-bead are shown in figures $8-10$ as the discharge approaches. As a result of being offset to the right of the axis, the bead is enveloped by the discharge starting from the left. As this is a negative corona discharge, the electron flux leads the positive ion flux as the edge of the plasma column approaches the anode. As such, the electrons first reach and begin enveloping the bead (1.6 ns) with densities of $10^{12} \mathrm{~cm}^{-3}$ (about a factor of 2 larger than the ions) while also charging the left side of the bead. By $1.7 \mathrm{~ns}$, the electrons enter the top vertical pore, increasing in density to $10^{10}-10^{11} \mathrm{~cm}^{-3}$. This pore penetrating flux is due to the direction of the drift in the electric field being in the orientation of the pore. The full
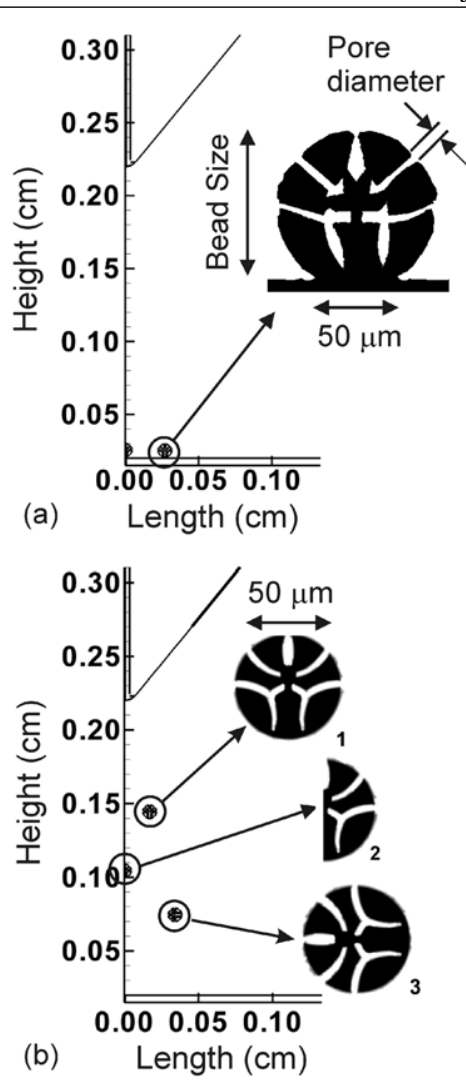

Figure 6. Arrangement of porous micro-beads in the discharge. (a) Micro-beads placed on the lower metal electrode and $(b)$ suspended in the discharge volume. The beads are numbered 1,2 and 3 from top to bottom. The beads are 30-90 $\mu \mathrm{m}$ in diameter with pore sizes of a few micrometers.

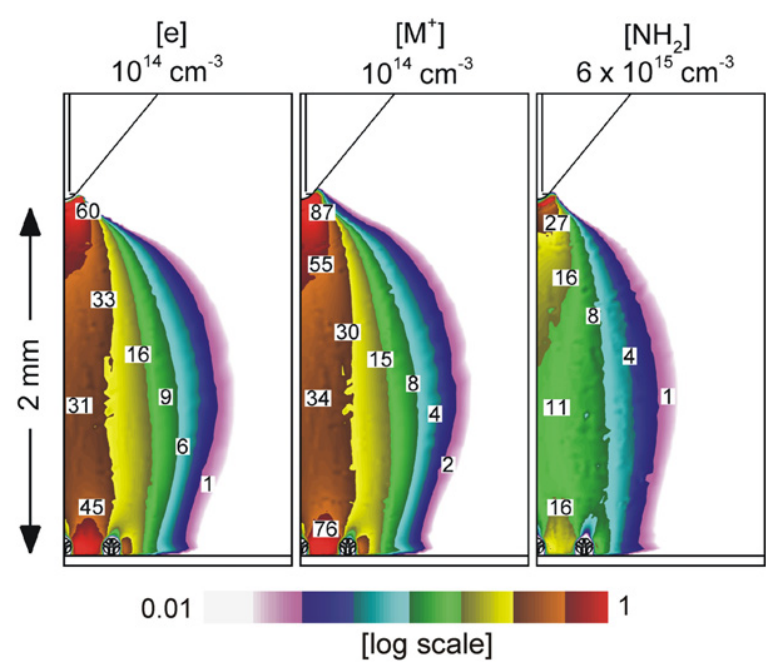

Figure 7. Densities of electrons, positive ions and $\mathrm{NH}_{2}$ at the end of the avalanche with $90 \mu \mathrm{m}$ polymer beads with pore diameter of $4 \mu \mathrm{m}$ placed on the grounded electrode. The discharge conditions are $\mathrm{He} / \mathrm{NH}_{3} / \mathrm{H}_{2} \mathrm{O}=98 / 1 / 1$ with an applied voltage of $-5 \mathrm{kV}$ to the upper electrode. The contour labels are percentages of the maximum value noted in each figure.

interior of the pore is eventually negatively charged. There is some penetration of electrons into the pores with openings on the side of the bead which are oriented more horizontally. However since the direction of net drift is nearly perpendicular 
$[\mathrm{e}] \mathrm{cm}^{-3}$

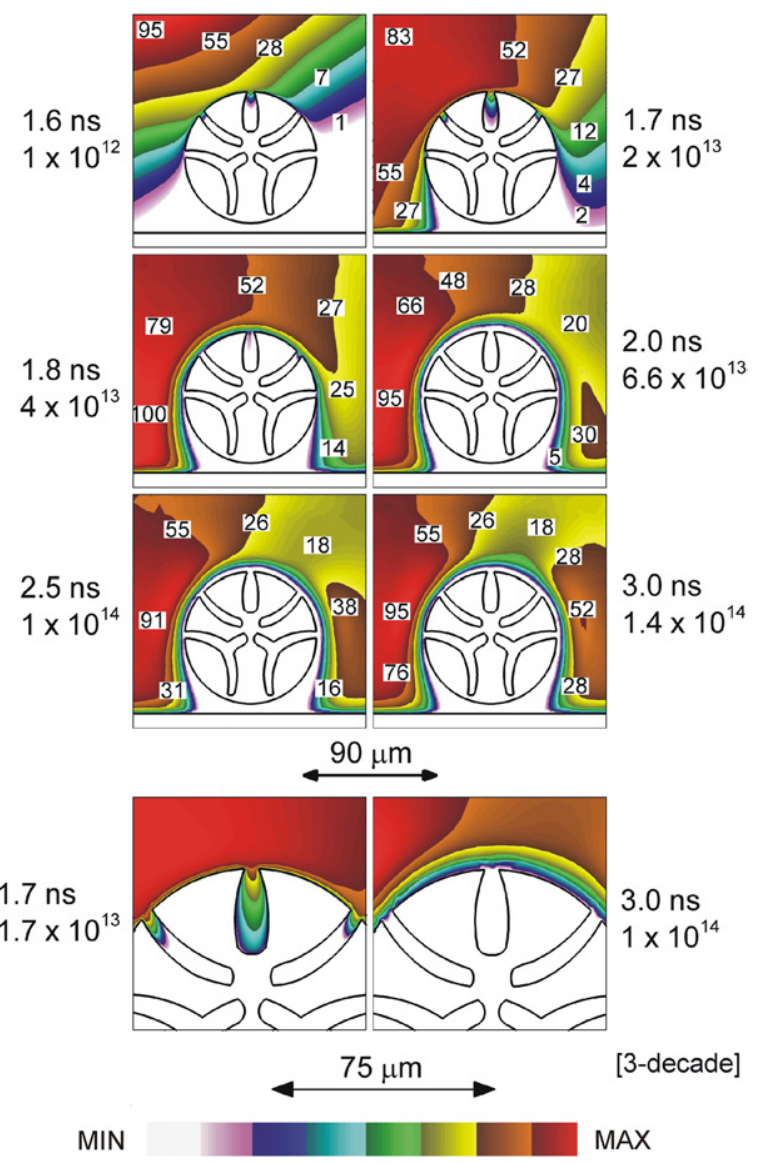

Figure 8. Electron density in the vicinity of the micro-bead as the avalanche approaches and envelopes the bead. The region around the topmost pore is enlarged in the lower figure. Electrons penetrate into the pore favorably oriented to the avalanche to $10^{11} \mathrm{~cm}^{-3}$ for $0.2 \mathrm{~ns}$ duration before withdrawing. The discharge conditions are the same as in figure 7. The contour labels are percentages of the maximum value noted in each figure.

to the orientation of these pores, the charging of the interior side wall prevents significant further penetration of electrons. The surfaces in the interior of the pores charge to the local floating potential corresponding to the temperature of electrons in the leading edge of the avalanche, about $4 \mathrm{eV}$.

When the discharge is fully developed, the Debye length in the vicinity of the pore openings is a few micrometers and is commensurate with the size of the openings. As such, the plasma is not able to conformally fit inside the pores. As the sheath fully develops in and around the pores, some of the early arriving electrons are expelled from the pores. Charging of the exterior of the bead results in an electron depleted sheath enveloping the bead. By $2 \mathrm{~ns}$, the avalanche closes the gas gap which increases the electron density to $10^{14} \mathrm{~cm}^{-3}$ around the bead.

The total positive ion density lags behind that of the electrons when the avalanche front first reaches the bead. As the electron and ion densities increase to $10^{13} \mathrm{~cm}^{-3}$ around the beads (1.8-2.0 ns), ambipolar forces constrain their densities to be nearly equal. The exception is in the sheath surrounding the beads and inside the pores where positive ion densities increase to $10^{11} \mathrm{~cm}^{-3}$ at $1.7 \mathrm{~ns}$.

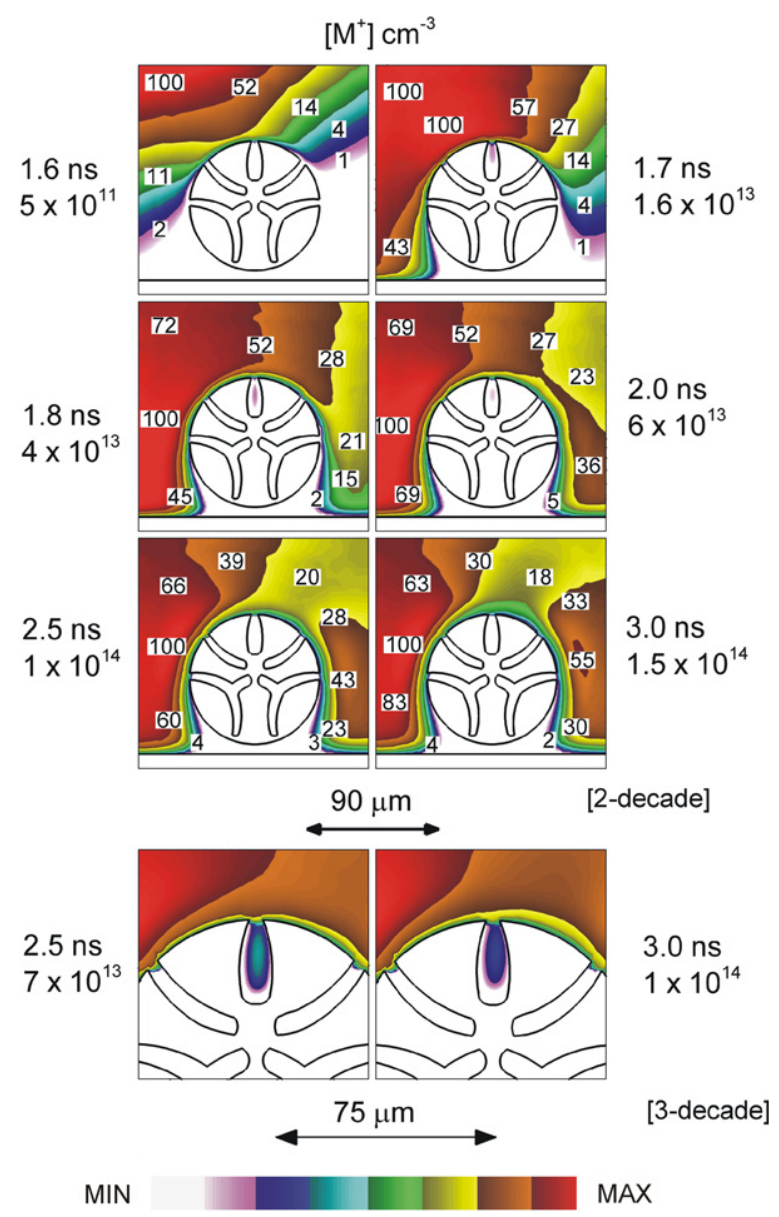

Figure 9. Positive ion density in the vicinity of the micro-bead as the avalanche approaches and envelopes the bead. The region around the topmost pore is enlarged in the lower figure. Positive ions more deeply penetrate into the pore favorably oriented to the avalanche. The discharge conditions are the same as in figure 7. The contour labels are percentages of the maximum value noted in each figure.

The $\mathrm{NH}_{2}$ densities near the bead during the pulse are shown in figure 11. During this short time (a few nanosecond), the $\mathrm{NH}_{2}$ molecules do not appreciably move by either diffusion or advection from their point of production by electron impact dissociation of $\mathrm{NH}_{3}$. As such, the $\mathrm{NH}_{2}$ density largely mirrors that of the electron density. Since there is some penetration of electrons into the top vertical pore, there is some $\mathrm{NH}_{2}$ production in the pore and so its density increases to $10^{12} \mathrm{~cm}^{-3}$ at $1.7 \mathrm{~ns}$. There is little $\mathrm{NH}_{2}$ production in the other pores due to the lack of electron penetration. Since $\mathrm{NH}_{2}$ is not depleted by reactions on this time scale, its density integrates as more electron impact dissociation occurs, and by $3 \mathrm{~ns}$, the $\mathrm{NH}_{2}$ density surrounding the micro-bead has risen to $10^{15} \mathrm{~cm}^{-3}$.

The plasma is essentially extinguished a few tens of nanoseconds after the discharge pulse by dissociative recombination and ion-ion recombination. Neutral chemistry dominates in the interpulse period as the longer lived radicals continue to react with each other and diffuse into the pores. For example, the bulk densities of $\mathrm{H}, \mathrm{OH}$ and $\mathrm{NH}_{2}$ radicals at the end of the $100 \mu$ s interpulse period are shown in figure 12(a). The maximum density of $\mathrm{H}$ radicals in the bulk plasma prior to the next discharge pulse is $6 \times 10^{14} \mathrm{~cm}^{-3}$ and is centered 


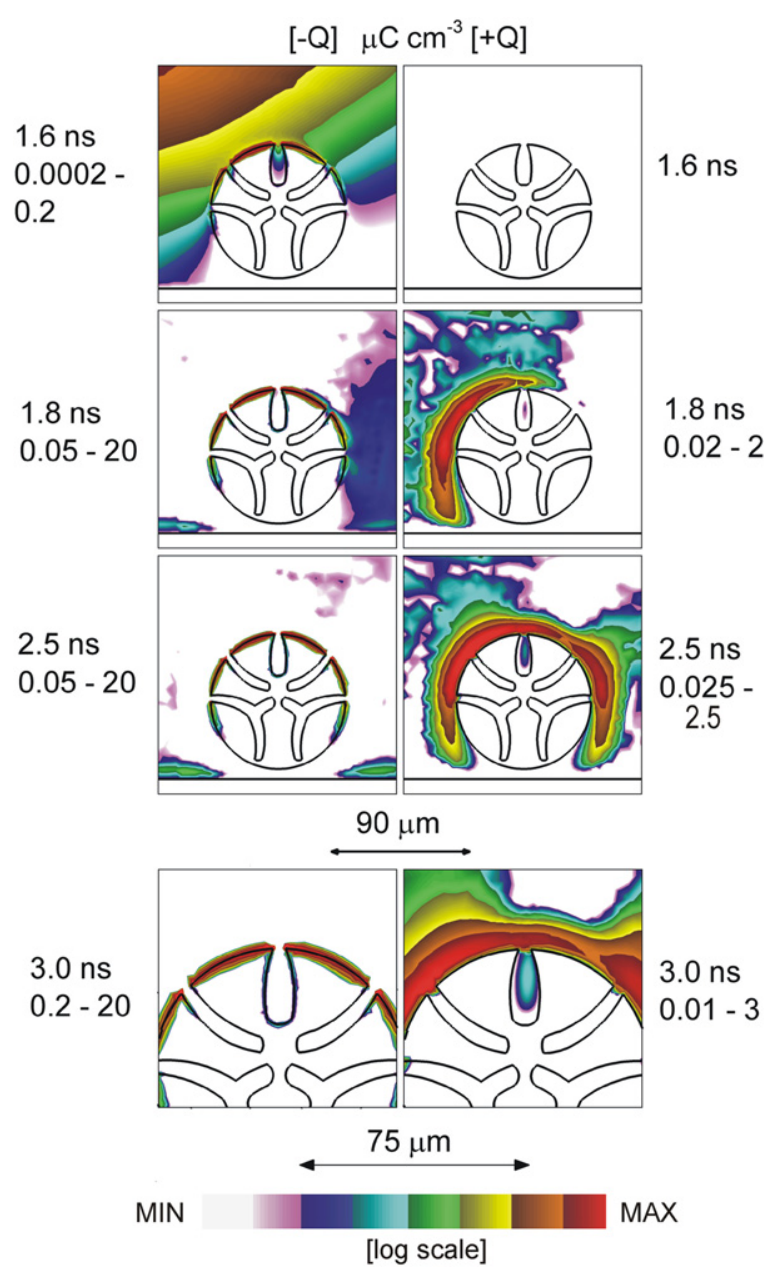

Figure 10. Net negative charge (left) and net positive charge (right) in the vicinity of the micro-bead as the avalanche approaches and envelopes the bead. The region around the topmost pore is enlarged in the lower figure. Charging and sheath formation occurs first on the left side of the bead. The discharge conditions are the same as in figure 7 . The range of values plotted in each figure is noted.

on axis where its production is highest. The density of $\mathrm{NH}_{2}$ $\left(6 \times 10^{12} \mathrm{~cm}^{-3}\right)$ peaks off-center, as much of the $\mathrm{NH}_{2}$ near the axis is consumed by rapid three-body reactions forming $\mathrm{N}_{2} \mathrm{H}_{4}$ (equation (18)) and reforming $\mathrm{NH}_{3}$. The density of $\mathrm{OH}$ at the end of the interpulse period is $10^{12} \mathrm{~cm}^{-3}$ in the bulk and decreases approaching the micro-beads due to the more rapid consumption of $\mathrm{OH}$ by surface reactions which form surface radicals (equation (30)).

The densities of $\mathrm{H}, \mathrm{OH}$ and $\mathrm{NH}_{2}$ in the vicinity of the micro-bead are shown in figure $12(b)$. As $\mathrm{OH}$ radicals diffuse into the pores where the diffusion length is small, they are rapidly consumed by surface reactions. Consequently, the $\mathrm{OH}$ density deep within the pores decreases by as much as a factor of 100 relative to its density near their openings. In contrast to the $\mathrm{OH}$ radicals, $\mathrm{H}$ atoms have a higher density $\left(10^{14} \mathrm{~cm}^{-3}\right)$ and are less reactive with the surface and so penetrate deeply into the pores. Though $\mathrm{NH}_{2}$ radicals react rapidly with radical surface sites (equation (33)), these radical sites are dominantly produced by $\mathrm{OH}$ which does not penetrate deeply into the pores. The density of surface radicals in the pores is small which limits the rate of consumption of $\mathrm{NH}_{2}$. As a result,

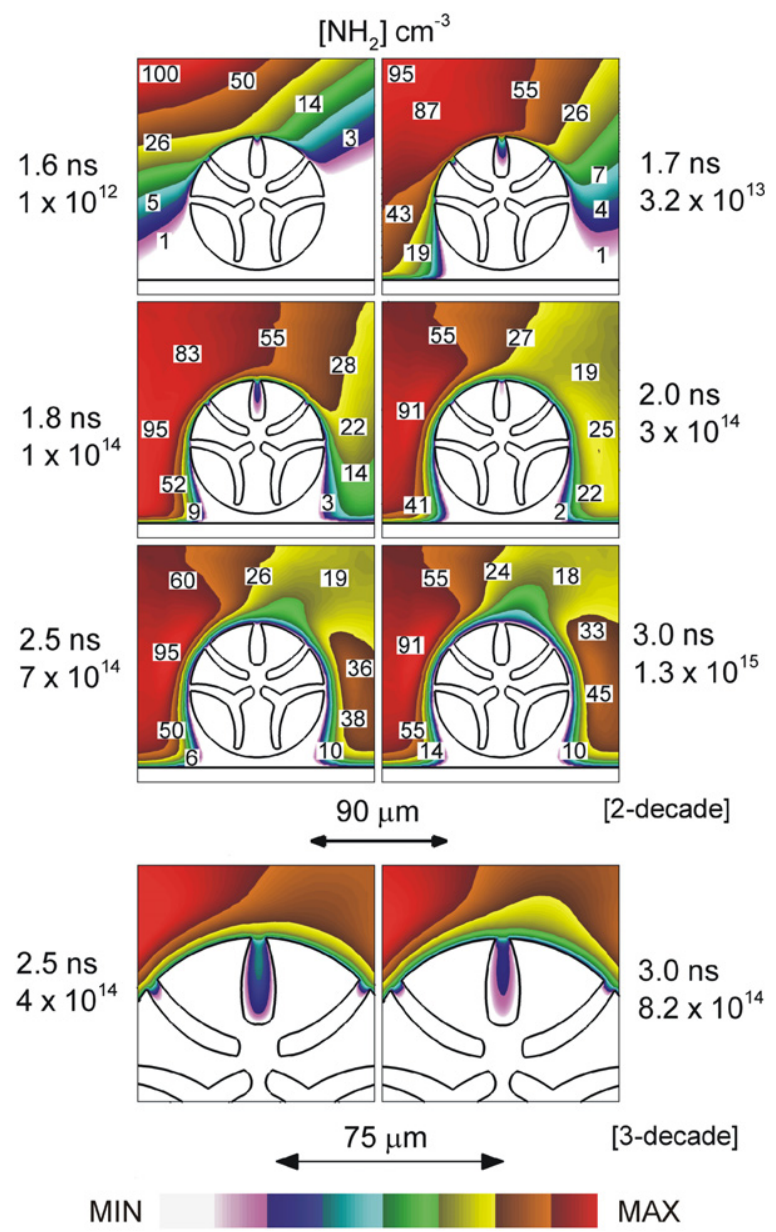

Figure 11. $\mathrm{NH}_{2}$ density in the vicinity of the micro-bead as the avalanche approaches and envelopes the bead. The region around the topmost pore is enlarged in the lower figure. At these early times, the $\mathrm{NH}_{2}$ density mirrors that of the electron density responsible for its production. The contour labels are percentages of the maximum value noted in each figure.

there is no appreciable gradient in the $\mathrm{NH}_{2}$ density within the pores.

The variation in $\mathrm{NH}_{2}$ density in discharges with different sizes of the micro-beads $(30-90 \mu \mathrm{m})$ while keeping the size of the pore opening constant $(4 \mu \mathrm{m})$ was examined. The $\mathrm{NH}_{2}$ density for these cases after the discharge pulse and at the end of the interpulse period are shown in figure 13(a). At the end of the discharge pulse, the density of $\mathrm{NH}_{2}$ outside the microbead generally increases with the size of the micro-bead. The larger the bead, the larger its capacitance, and so more electron current flows to its surface prior to the sheath fully forming. This allows for more electron impact dissociation to occur near its surface. At the end of the IP, the densities of $\mathrm{NH}_{2}$ inside the pores are not strong functions of bead size, though tending to be larger for the smaller beads. This effect is dominated by the density of $\mathrm{NH}_{2}$ outside the bead which provides the source for its diffusion into the pores.

There is a significant gradient in the density of $\mathrm{OH}$ inside the pores. $\mathrm{OH}$ is consumed by surface reactions that produce the radical sites, $\mathrm{R}^{\cdot}$, and which are the precursors for $\mathrm{NH}_{2}$ to form amine sites. The distance the $\mathrm{OH}$ radicals must traverse to reach deeply into the pores is longer as the bead size increases 


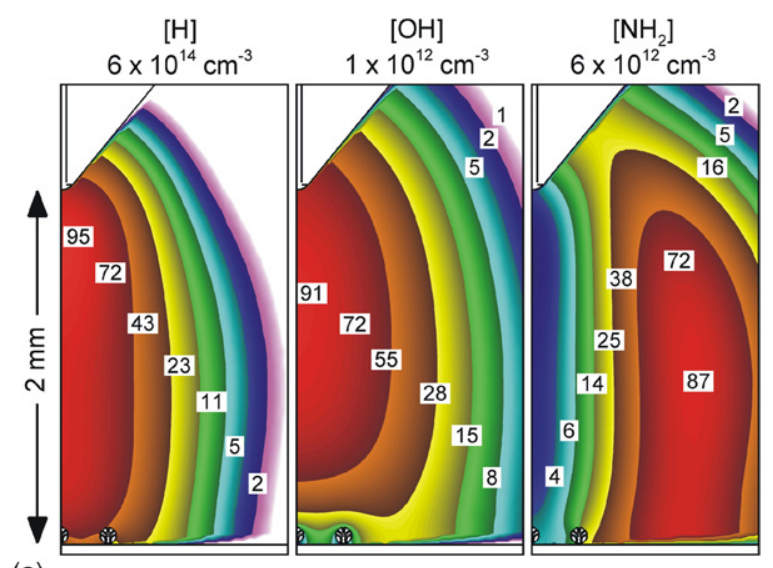

(a)

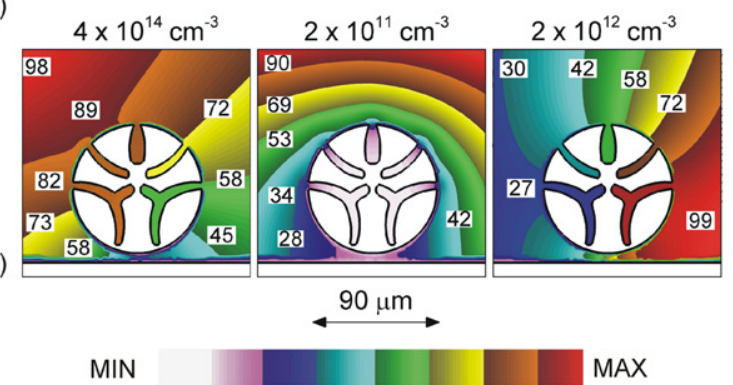

Figure 12. The density of $\mathrm{H}, \mathrm{OH}$ and $\mathrm{NH}_{2}$ after the interpulse period in $(a)$ the bulk and $(b)$ near the micro-bead. The high reactivity of $\mathrm{OH}$ results in its significant depletion before it fully penetrates into the pores. The conditions are the same as in figure 7. The contour labels are percentages of the maximum value noted in each figure.

and so the likelihood for reactions is greater. The availability of $\mathrm{R}^{\bullet}$ sites is therefore smaller deep in the pores of the larger beads. The coverages of amino $\left(\mathrm{R}-\mathrm{NH}_{2}\right)$ groups on the microbeads for 30, 60 and $90 \mu \mathrm{m}$ beads after $0.4 \mathrm{~s}$ of treatment are shown in figure $13(b)$. The $\mathrm{R}-\mathrm{NH}_{2}$ coverage on the outer surfaces of the micro-bead decreases with increasing size of the bead due to the larger surface area for consumption of the limited supply of initiating $\mathrm{OH}$ radicals. Deep into the pores, the $\mathrm{R}-\mathrm{NH}_{2}$ coverage decreases by an order of magnitude due to the lower availability of $\mathrm{R}^{\bullet}$ for $\mathrm{NH}_{2}$ to bind with.

The densities of $\mathrm{NH}_{2}$ radicals after the discharge pulse and interpulse period for another set of discharges with $90 \mu \mathrm{m}$ beads having different pore sizes are shown in figure 14(a). The density of $\mathrm{NH}_{2}$ is larger inside the pores having larger openings during the pulse due to the greater penetration of electrons. However, there is little change in its density at the end of the interpulse period as diffusion is sufficiently rapid in both cases to fill the pores. The coverages of amine groups for pore openings of 2, 4 and $8 \mu \mathrm{m}$ are shown in figure $14(b)$. Since the radical densities inside the pores are not very different, similar surface coverages of amine groups result, though the coverage deep in the pores is higher for larger pore openings.

\section{Functionalization of porous micro-beads suspended in $\mathrm{He} / \mathrm{O}_{2} / \mathrm{H}_{2} \mathrm{O}$ discharges}

Rapid functionalization of hydrocarbon polymers can usually be achieved in $\mathrm{O}_{2}$ containing discharges due to the abundant $\mathrm{O}$ atom densities produced by electron impact dissociation of
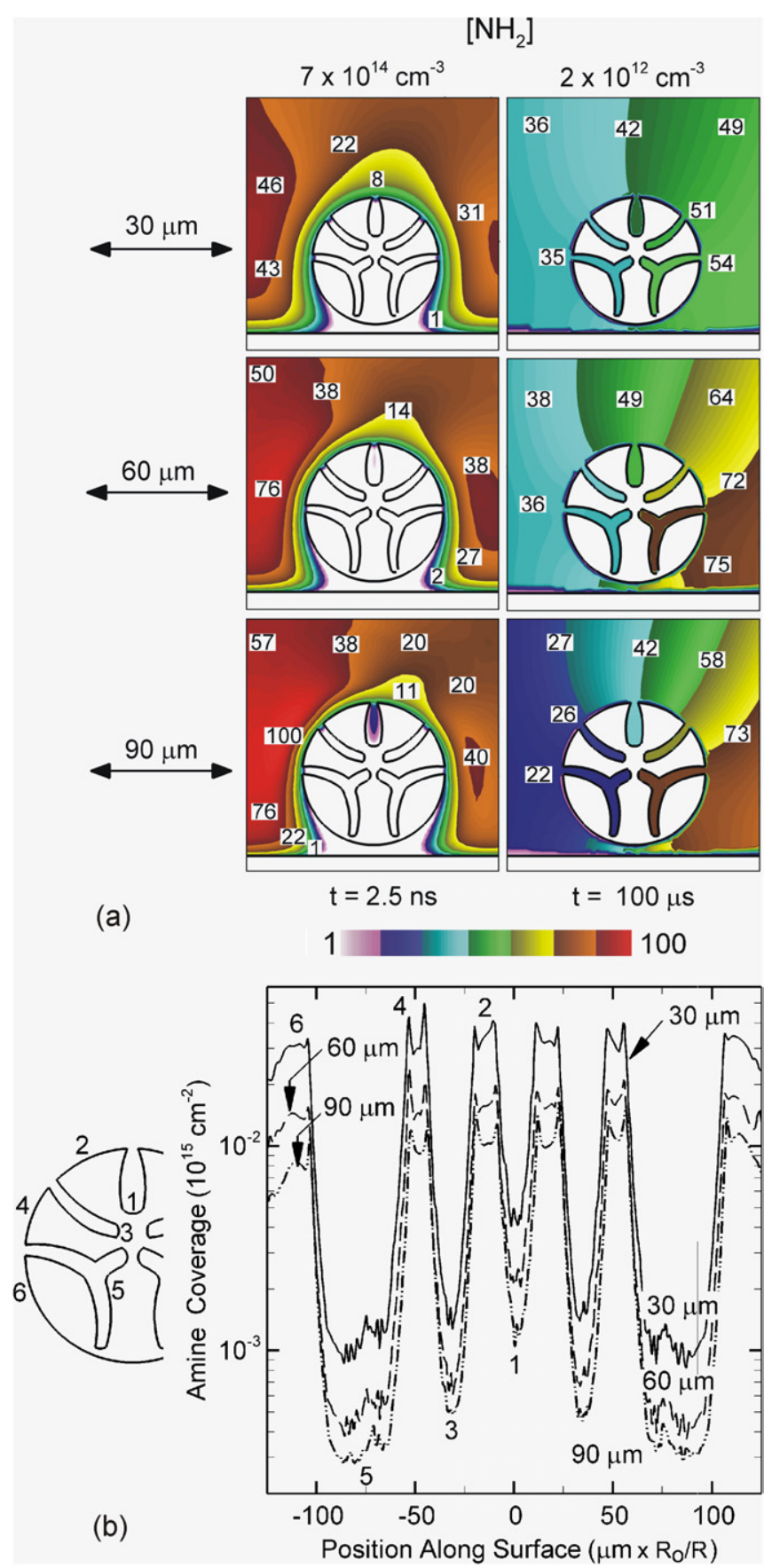

Figure 13. Properties for bead sizes of 30,60 and $90 \mu \mathrm{m}$.

(a) Densities of $\mathrm{NH}_{2}$ radicals after the discharge pulse and after the interpulse period. $(b)$ The coverage of $\mathrm{R}-\mathrm{NH}_{2}$ for different diameter beads as a function of position along the surface. The numbers in the inset and along the plot identify the location along the surface. The surface dimensions of the 60 and $90 \mu \mathrm{m}$ beads have been normalized to overlay with results for the $90 \mu \mathrm{m}$ bead. The contour labels are percentages of the maximum value noted in each figure.

$\mathrm{O}_{2}$ that initiate surface reactions, and the fact that the parent gas can affix to radical sites. In the case of functionalizing micro-beads, the surface coverages might still be non-uniform if the fluxes are geometrically constrained, as with micro-beads placed on a surface. A different strategy might be to suspend the beads in the gas flow, a possibility with beads tens of micrometers in size at atmospheric pressure. This provides 
$\left[\mathrm{NH}_{2}\right]$

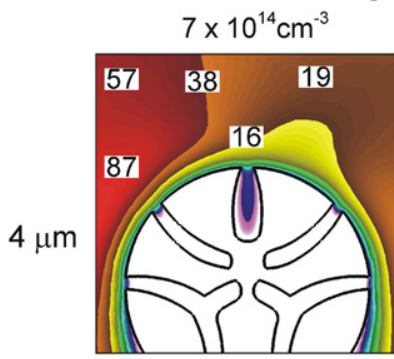

$2 \times 10^{12} \mathrm{~cm}^{-3}$
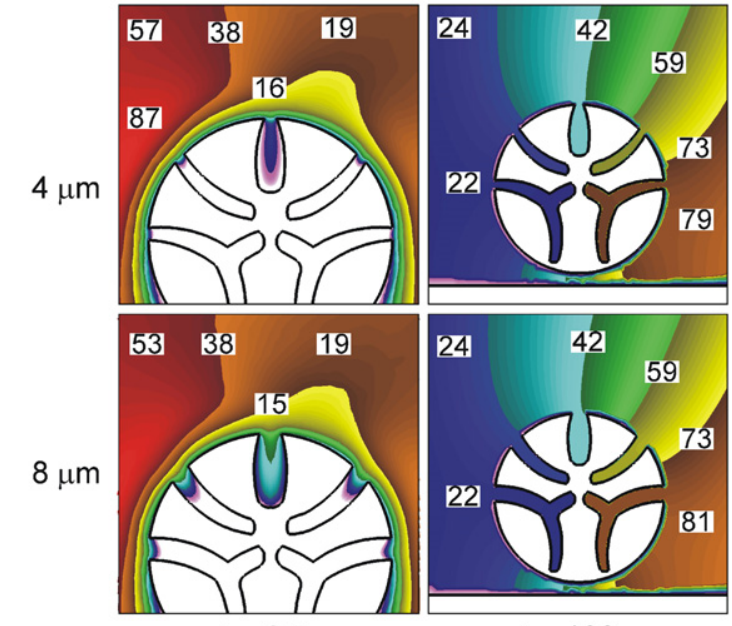

(a)
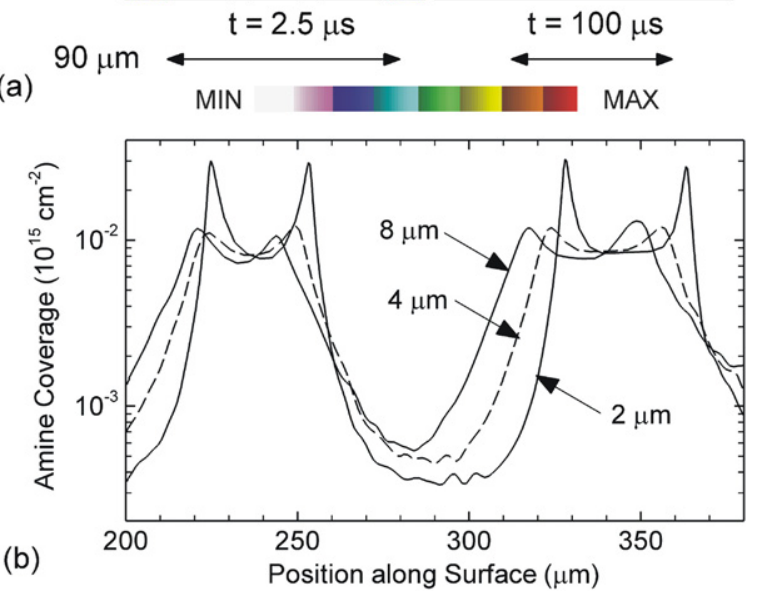

Figure 14. Properties for $90 \mu \mathrm{m}$ micro-beads with different pore sizes. (a) Densities of $\mathrm{NH}_{2}$ radicals after the discharge pulse and after the interpulse period for pore sizes of 4 and $8 \mu \mathrm{m}$. (b) The coverage of $\mathrm{R}-\mathrm{NH}_{2}$ along the surface of the bead for pore sizes of 2 , 4 and $8 \mu \mathrm{m}$. The contour labels are percentages of the maximum value noted in each figure.

the possibility for the plasma produced radicals to envelope the particle and improve the uniformity of functionalization.

We investigated the atmospheric pressure discharge functionalization of porous polymer micro-beads suspended in $\mathrm{He} / \mathrm{O}_{2} / \mathrm{H}_{2} \mathrm{O}$ mixtures. In actual operation, the beads will translate through the discharge and possibly rotate. However to simplify the model, we assumed that the beads were suspended in the discharge during $1 \mathrm{~ms}$ (10 pulses) of processing without moving. The placement of three such suspended $90 \mu \mathrm{m}$ diameter beads is shown in figure $6(b)$.

Densities of electrons, $\mathrm{OH}, \mathrm{O}$ and $\mathrm{O}_{3}$ after 2.5 ns into the first discharge pulse in a $\mathrm{He} / \mathrm{O}_{2} / \mathrm{H}_{2} \mathrm{O}=89 / 10 / 1$ mixture with three suspended micro-beads are shown in figure 15. Electron densities of $10^{14} \mathrm{~cm}^{-3}$ are produced, which result in production of $10^{14} \mathrm{~cm}^{-3}$ of $\mathrm{O}$ atoms and $2 \times 10^{13} \mathrm{~cm}^{-3}$ of $\mathrm{OH}$ radicals. (By the end of the discharge pulse, the $\mathrm{O}$ atom density is $5 \times 10^{15} \mathrm{~cm}^{-3}$.) During this short discharge pulse, there is insufficient time for three-body reactions to produce significant amounts of $\mathrm{O}_{3}$, and so its density peaks at only $5 \times 10^{9} \mathrm{~cm}^{-3}$.

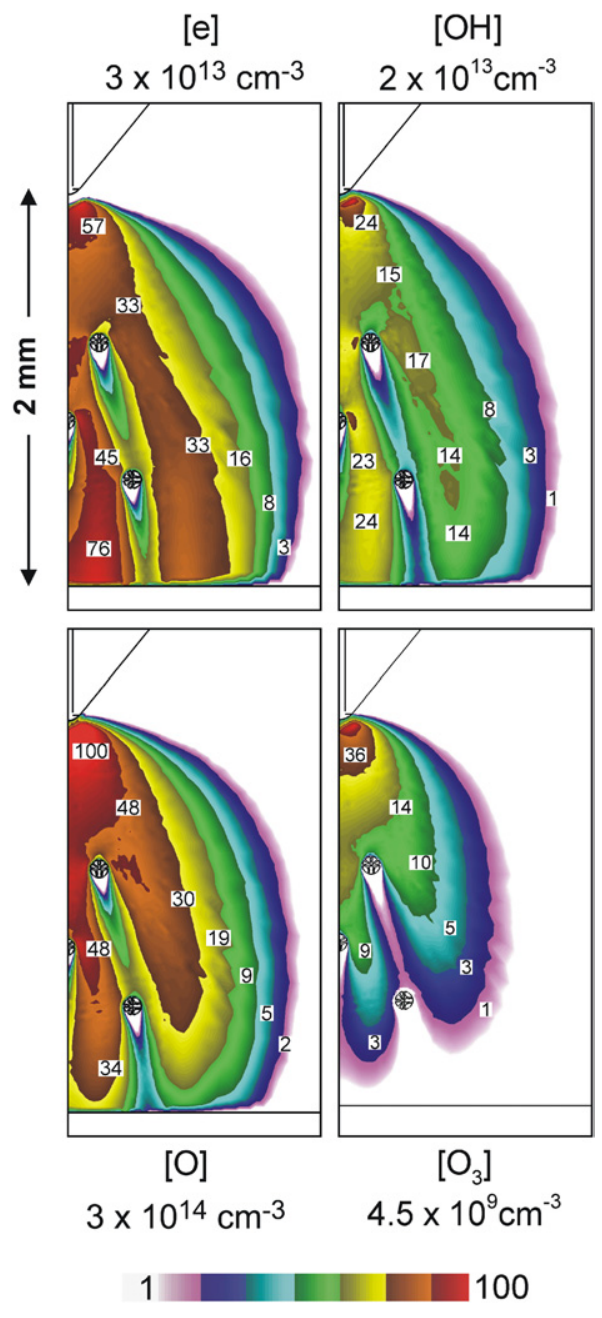

Figure 15. Densities of electrons, $\mathrm{OH}, \mathrm{O}$ and $\mathrm{O}_{3}$ during the discharge pulse in a $1 \mathrm{~atm}, \mathrm{He} / \mathrm{O}_{2} / \mathrm{H}_{2} \mathrm{O}=89 / 10 / 1$ mixture with suspended micro-beads. The plasma forms a wake around the particles as the avalanche passes by. The contour labels are percentages of the maximum value noted in each figure.

In this negative corona discharge, the direction of motion of electrons is from top to bottom. The micro-beads are electrically floating bodies in the discharge having diameters much larger than both the Debye lengths and the mean free paths of electrons and ions (a few micrometers) in the fully developed discharges. The beads can therefore form obstructions to the development of the discharge. This obscuring nature of the beads is shown in figure 15 by the wakes which trail downstream of each particle and which are nearly devoid of plasma. The wakes have lengths of a few bead diameters. The origin of these wakes is in part simply the obscuring nature of the particles as the avalanche front propagates past the particle. The particle also blocks photoionizing radiation originating from upstream in the discharge, which reduces the rate of avalanche in the shadow. A finite time is required for the plasma to diffuse laterally to fill in behind the obscuration. The wakes are intensified by charging of the particles.

The electron density in the vicinity of bead 1 (see figure $6(b)$ for placement) is shown in figure 16 as the avalanche front reaches and envelopes the bead. As the avalanche first 

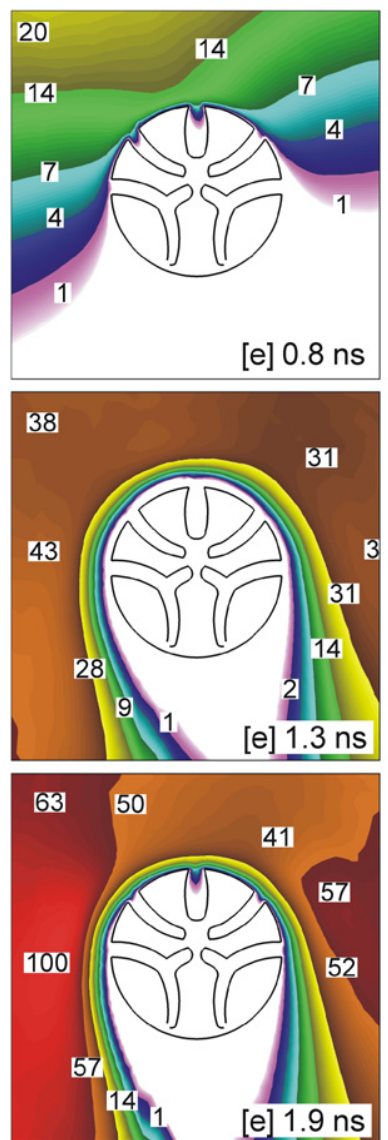

[e] $2.5 \times 10^{13} \mathrm{~cm}^{-3}$
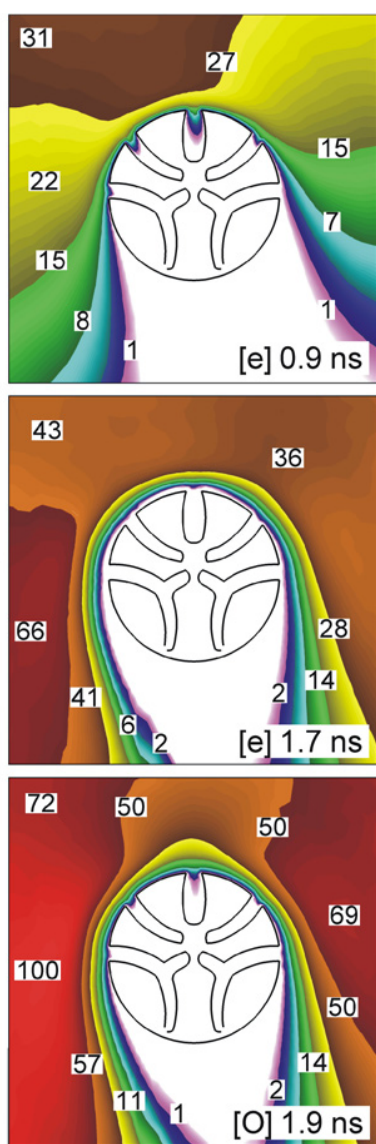

[O] $8 \times 10^{13} \mathrm{~cm}^{-3}$

\section{$1+100$}

Figure 16. Electron density in the vicinity of bead 1 as the avalanche passes by. The $\mathrm{O}$ atom density for the last time is also shown. The contour labels are percentages of the maximum value noted in each figure.

reaches the micro-bead $(0.8 \mathrm{~ns})$, its surface is uncharged. The electron density flows to the surface and into the pores of the bead $(0.9 \mathrm{~ns})$ as it charges towards the floating potential. A wake forms downstream of the bead roughly aligned with the direction of the electric field and the shadow of photo-ionizing radiation originating upstream. Since the electron temperature in the leading edge of the avalanche is higher than in the bulk plasma that follows and later envelopes the bead, the surface of the bead over-charges. That is, the magnitude of the negative charge density is larger than that corresponding to the floating potential density in the bulk plasma. The electrons then 'bounce back' from the surface $(1.3 \mathrm{~ns})$. Recall that electrons lead the ions at the front edge of the avalanche front. After a few tenths of a nanosecond, the ion density increases near the surface to nearly the same value as the electrons. This enables the surface charge to equilibrate with the local electron temperature (1.7 ns). A sheath begins to form (1.9 ns) which is slightly conformal to the top pore opening. Since in this short time, radicals do not significantly react, the $\mathrm{O}$ atom density produced around the bead at the end of the discharge pulse (also shown in figure 16) mirrors that of the electron density.

By the end of the following interpulse period, nonuniformities in radical densities around the particle resulting

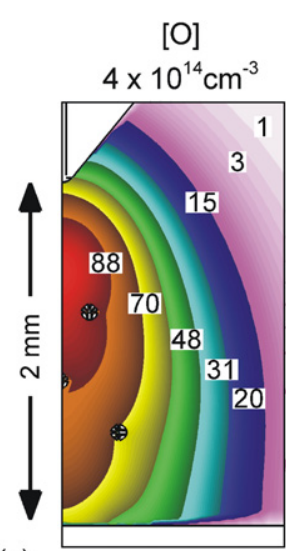

$[\mathrm{OH}]$

$\left[\mathrm{O}_{3}\right]$

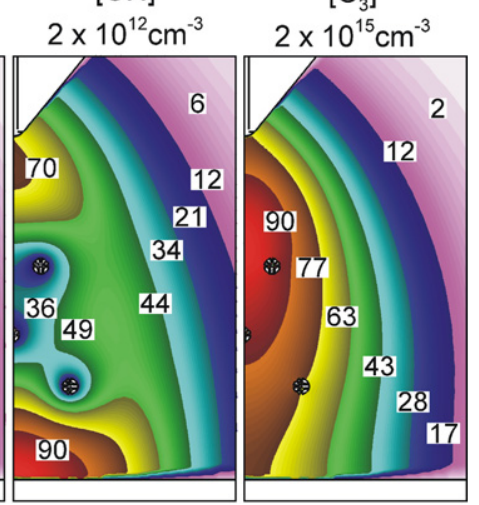

(a)

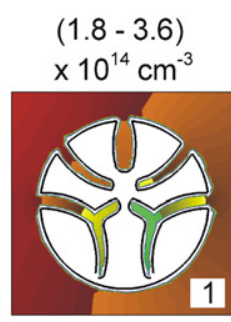

$10^{12} \mathrm{~cm}^{-3}$

$(1.2-1.7)$

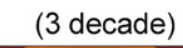

$\times 10^{15} \mathrm{~cm}^{-3}$
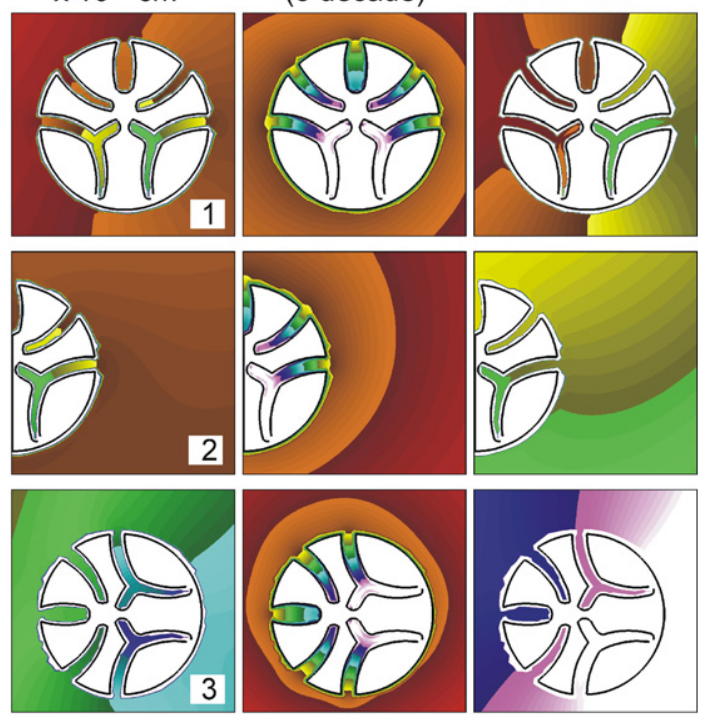

(b)

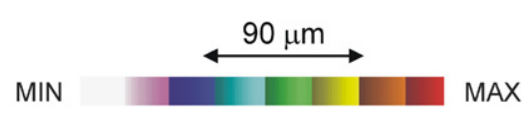

Figure 17. The density of $\mathrm{O}, \mathrm{OH}$ and $\mathrm{O}_{3}$ at the end of the interpulse period with suspended micro-beads. The conditions are the same as in figure 15. (a) Densities across the discharge gap. (b) Densities in the vicinity of each of the micro-beads. The radicals diffuse deep into the pores of the micro-bead smoothening out gradients. $\mathrm{OH}$ radicals are consumed on the surfaces of the micro-beads resulting in local gradients. In $(a)$ the contour labels are percentages of the maximum value noted in each figure. In $(b)$ the ranges of values plotted are noted.

from the plasma wake have been mitigated by diffusion. This is shown in figure 17 where the densities of $\mathrm{O}, \mathrm{OH}$ and $\mathrm{O}_{3}$ in the bulk and in the vicinity of the beads at the end of the IP are plotted. The gradients that do remain result primarily from the large scale structure of the discharge. The density of $\mathrm{O}$ atoms decreases from its post-discharge value of $5 \times 10^{15} \mathrm{~cm}^{-3}$ to $4 \times 10^{14} \mathrm{~cm}^{-3}$, the majority of the difference producing $\mathrm{O}_{3}$ (density of $2 \times 10^{15} \mathrm{~cm}^{-3}$ ). $\mathrm{O}$ is mildly reactive with the saturated PP surface (reaction probability $10^{-4}-10^{-3}$ ) and so there is some local consumption by the beads (note the depletion around bead 3). Penetration of $\mathrm{O}$ atoms into the smaller pores of the beads is hindered by its reactivity with the surface, but only by a factor of $2 . \mathrm{O}_{3}$ is less reactive (probability $10^{-6}$ ) and has small gradients near the beads 

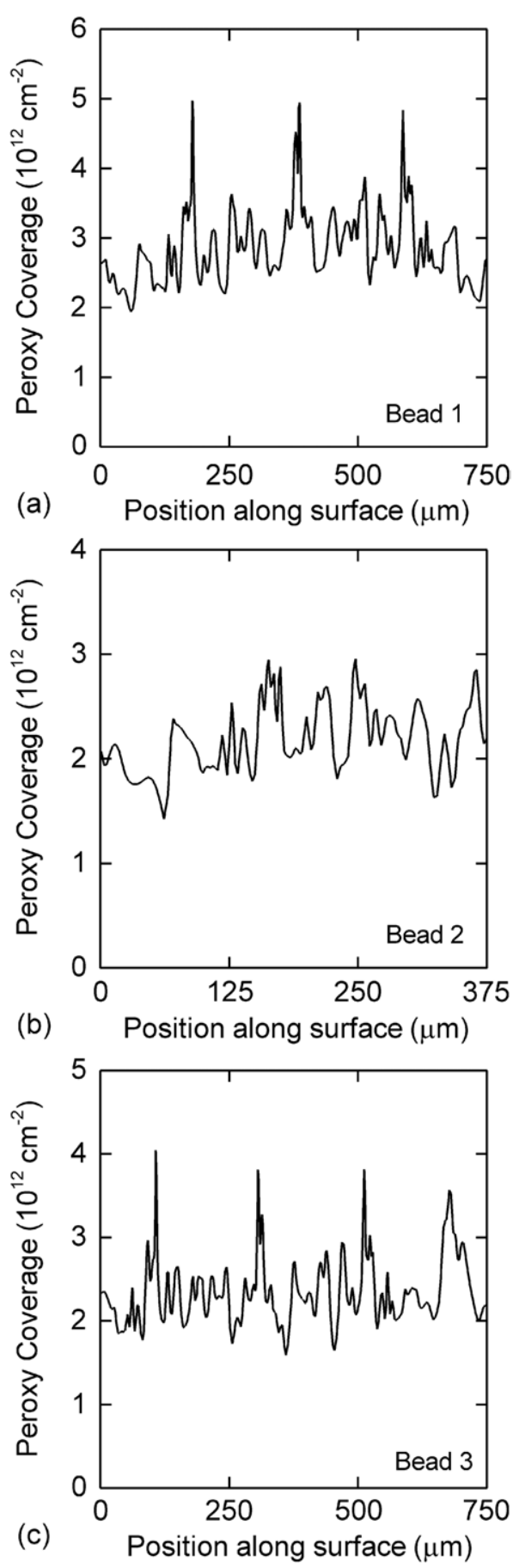

Figure 18. Surface coverage of peroxy groups on the different micro-beads after $1 \mathrm{~ms}$ of treatment. (a) Near the powered electrode, $(b)$ on the axis and $(c)$ off-axis near the grounded electrode. The conditions are the same as in figure 15 .

and in the pores. As $\mathrm{OH}$ is highly reactive with the surface (probability 0.1), there is significant depletion in the $\mathrm{OH}$ density in the gas phase around the beads. Although the radical densities inside the pores depend on the location of the microbead in the discharge, they are little affected by the orientation of their pore openings.

The surface reaction mechanism for functionalization of PP surfaces in $\mathrm{He} / \mathrm{O}_{2} / \mathrm{H}_{2} \mathrm{O}$ discharges is essentially the same as for the humid air discharges described in part I. The same reactive gas phase species $\left(\mathrm{O}, \mathrm{OH}\right.$ and $\left.\mathrm{O}_{3}\right)$ are generated in both cases. After $1 \mathrm{~ms}$ of treatment, the coverages of peroxy groups (R-OO•) along the surface of each of the micro-beads are shown in figure 18. (Recall that $\mathrm{R}-\mathrm{OO}^{*}$ is formed by passivation by $\mathrm{O}_{2}$ of an alkyl $\mathrm{R}^{\bullet}$ site which was created by $\mathrm{O}$ or $\mathrm{OH}$ abstracting $\mathrm{H}$ from the surface.) Although the surface coverages have local variation due to the view angles of surface sites to the plasma, in general the coverages are fairly uniform and are not particularly sensitive to the location of the bead in the discharge. The peaks in coverage are in large part a consequence of rapidly reacting $\mathrm{OH}$ creating $\mathrm{R}^{\bullet}$ sites on the outer surface of the bead and near the opening of the pores. The large $\mathrm{O}$ atom densities both within and outside the microbeads, and its moderate reactivity, enable $\mathrm{R} \cdot$ sites to be created fairly uniformly on both the inner and outer surfaces of the micro-beads.

\section{Concluding remarks}

The functionalization of rough PP surfaces and porous microbeads with characteristic features of a few micrometers using repetitively pulsed atmospheric pressure discharges was investigated. The treatment of flat but rough surfaces was examined in $\mathrm{He} / \mathrm{NH}_{3} / \mathrm{H}_{2} \mathrm{O}$ discharges. It was found that $\mathrm{R}-\mathrm{NH}_{2}$ coverages of $5-10 \%$ can be achieved but the uniformity was generally low due to the necessity to create alkyl sites $\left(\mathrm{R}^{\bullet}\right)$ by oxygen containing species such as $\mathrm{OH}$. Gas composition can be used to adjust the coverage of $\mathrm{R}-\mathrm{NH}_{2}$ but there will generally be a tradeoff between rapid and uniform functionalization of $\mathrm{R}-\mathrm{NH}_{2}$, and the possibility of affixing $\mathrm{O}$-containing species to the surface. The treatment of porous micro-beads in $\mathrm{He} / \mathrm{NH}_{3} / \mathrm{H}_{2} \mathrm{O}$ discharges was found to vary with the size of the micro-bead and pore characteristics due in large part to the reactivity of $\mathrm{OH}$ used to initiate the functionalization. Suspending microbeads in $\mathrm{He} / \mathrm{O}_{2} / \mathrm{H}_{2} \mathrm{O}$ discharges produces a plasma wake downstream of the beads during avalanche of the discharge but diffusion of radicals during the interpulse period generally mitigates the wake. Rapid surface functionalization is realized with comparable treatment of the outer and porous interior surfaces due to the ability of $\mathrm{O}$ atoms to penetrate into the pores.

\section{Acknowledgments}

This work was supported by the National Science Foundation (CTS-0520368). The authors thank Dr Mark Strobel for his advice and guidance.

\section{References}

[1] Sefton M V, Sawyer A, Gorbet M, Black J P, Cheng E, Gemmell C and Pottinger-Cooper E $2001 \mathrm{~J}$. Biomed. Mater. Res. 55447

[2] Koenig U, Nitschke M, Menning A, Sperling C, Simon F, Arnhold C, Werner C and Jacobasch H-J 1999 Surf. Coat. Technol. 116-119 1011

[3] Siow K S, Britcher L, Kumar S and Griesser H J 2006 Plasma Proc. Polym. 3392 
[4] Hayat U, Tinsley A M, Calder M R and Clarke D J 1992 Biomaterials 13801

[5] Holmes S and Schwartz P 1990 Comput. Sci. Technol. 38

[6] Liu Z M, Xu Z-K, Wang J-Q, Yang Q, Wu J and Seta P 2003 Eur. Polym. J. 392291

[7] Chim H, Ong J L, Schantz J-T, Hutmacher D W and Agrawal C M 2002 J. Biomed. Mater. Res. A65 327

[8] Øye G, Roucoules V, Cameron A M, Oates L J, Cameron N R, Steel P G, Badyal J P S, Davis B G, Coe D and Cox R 2002 Langmuir 188996

[9] Øye G, Roucoules V, Oates L J, Cameron A M, Cameron N R, Steel P G, Badyal J P S, Davis B G, Coe D M and Cox R A 2003 J. Phys. Chem. B 1073496

[10] Kim J W and Choi H S 2002 J. Appl. Polym. Sci. 832921

[11] Sipehia R, Chawla A S and Chang T M S 1986 Biomaterials 7471

[12] Koontz S L, Devivar R V, Peltier W J, Pearson J E, Guillory T A and Fabricant J D 1999 Colloid Polym. Sci. 277557

[13] Bretagnol F, Tatoulian M, Arefi-Khonsari F, Lorang G and Amouroux J 2004 React. Funct. Polym. 61221
[14] Sharma R, Trigwell S, Biris A S, Sims R A and Mazumder M K 2003 IEEE Trans. Ind. Appl. 3987

[15] Bhoj A N and Kushner M J 2008 Plasma Sources Sci. Technol. 17035024

[16] Arakoni R A, Bhoj A N and Kushner M J 2007 J. Phys. D: Appl. Phys. 402476

[17] Meyer-Plath A A 2002 PhD Dissertation Ernst-Moritz-Arndt-Universität, Greifswald

[18] Alfassi Z B (ed)1998 N-Centered Radicals (West Sussex, England: Wiley)

[19] Herron J T 1999 J. Phys. Chem. Ref. Data 281453

[20] 1998 NIST Standard Reference Database 17-2Q98 (Gaithersburg, MD: National Institute of Standards and Technology)

[21] Lesclaux R and Desmissy M 1982 Int. J. Chem. Kinetics 141

[22] Dorai R and Kushner M J 2003 J. Phys. D: Appl. Phys. 36666

[23] Kuvaldina E V, Rybkin V V, Titov V A, Shikova T G and Shutov D A 2004 High Eng. Chem. 38411

[24] Tochikubo F, Chiba T and Watanabe T 1999 Japan. J. Appl. Phys. 385244

[25] Skurat V E and Dorofeev Y I 1994 Angew. Makromol. Chem. 216205 